University of Michigan Law School

University of Michigan Law School Scholarship Repository

2020

\title{
Does Capital Bear the U.S. Corporate Tax After All? New Evidence from Corporate Tax Returns
}

\author{
Edward Fox \\ University of Michigan Law School, edfox@umich.edu
}

Available at: https://repository.law.umich.edu/articles/2189

Follow this and additional works at: https://repository.law.umich.edu/articles

Part of the Banking and Finance Law Commons, Taxation-Federal Commons, and the Tax Law Commons

\section{Recommended Citation}

Fox, Edward Gellis. "Does Capital Bear the U.S. Corporate Tax After All? New Evidence from Corporate Tax Returns." J. Empirical Legal Stud. 17, no. 1 (2020): 71-115.

This Article is brought to you for free and open access by the Faculty Scholarship at University of Michigan Law School Scholarship Repository. It has been accepted for inclusion in Articles by an authorized administrator of University of Michigan Law School Scholarship Repository. For more information, please contact mlaw.repository@umich.edu. 


\title{
Does Capital Bear the U.S. Corporate Tax After All? New Evidence from Corporate Tax Returns
}

\author{
Edward Fox
}

\begin{abstract}
This article uses U.S. corporate tax return data to assess how government revenue would have changed if, over the period 1957-2013, corporations had been subject to a hypothetical corporate cash flow tax-that is, a tax allowing for the immediate deduction of investments in long-lived assets like equipment and structures-rather than the corporate tax regime actually in effect. Holding taxpayer behavior fixed, the data indicate actual corporate tax revenue over the most recent period (1995-2013) differed little from that under the hypothetical cash flow tax. This result has three important implications. First, capital owners appear to bear a large fraction of the corporate tax today. This is because economic theory holds that corporate cash flow taxes are largely borne by capital owners and my result implies that the actual tax behaves in practice much like a cash flow tax. This theory is embodied in the Treasury's most recent model of corporate tax incidence. Applying the model to my results implies that only a small portion (2-10 percent) of the U.S. corporate tax was borne by labor in the years before the 2017 Act and thus capital providers are the primary beneficiaries of the Act's large corporate rate cut. Second, the results suggest that the United States could switch fully over to a cash flow tax, which is likely to be administratively simpler for both the government and corporations, at relatively low revenue cost. Third, the impact of fully switching to a cash flow tax on the operations of the real economy and its efficiency are likely to be fairly small. This is precisely because the corporate tax has already evolved to largely mimic a cash flow tax, and the article explores the reasons underlying this evolution using a novel dataset.
\end{abstract}

\section{INTRODUCTION}

The centerpiece of the 2017 Tax Act was the reduction in the corporate tax rate from 35 percent to 21 percent. ${ }^{1}$ The Congressional Budget Office (CBO 2018) estimates the

\footnotetext{
*Address correspondence to Assistant Professor of Law, University of Michigan Law School, 625 S. State St., Ann Arbor, MI 48109; email: edfox@umich.edu.

I would like to thank Dawn Chutkow and the two anonymous referees for their help in editing and improving the article, as well as the participants at the ALEA, NTA and CELS conferences along with Reuven Avi-Yonah, Ian Ayres, Dhammika Dharmapala, Katarzyna Habu, Jacob Goldin, Zach Liscow, Paul Rhode, Joel Slemrod, Nora Sennett, and, especially, Jim Hines for their comments and suggestions. All errors are of course my own.

${ }^{1}$ The previous name of the bill, the Tax Cuts and Jobs Act, was stricken shortly before passage. I will refer to it as the 2017 Tax Act or simply the 2017 Act.
} 
rate cut will reduce tax revenue by well over $\$ 1$ trillion over the next decade. The Act also allows for the immediate deduction ("expensing") of nearly all physical equipment purchased by businesses. ${ }^{2}$ The political parties are-to say the least-divided on the likely effects of the rate cut. Republicans claim that the changes will spur capital accumulation, raising labor productivity, which in turn will lead to higher employment and increasing wages. Democrats, by contrast, have painted the corporate rate cut as a giveaway to wealthy shareholders who will receive the vast majority, if not all, of the benefits. The academic debate, more than 50 years after Harberger (1962) published his seminal analysis of corporate tax incidence, is more civil, but not much less divergent. Scholars have used several methodologies and even those using similar methodologies have reached widely different conclusions, ranging from labor bearing almost 0 percent to more than 100 percent of corporate taxes (Auerbach 2018).

This article gives another view of the (corporate tax incidence) cathedral using new empirical evidence from aggregate U.S. corporate tax return data. It uses these data to construct a hypothetical cash flow tax covering 1957 to 2013, though I focus more intensely on 1995-2013 (the "primary study period"). ${ }^{3}$ As the name implies, a cash flow tax allows businesses to deduct their expenses as soon as the cash is paid. This includes allowing an immediate deduction for investments in long-lived assets like equipment and structures. By contrast, under an income tax like the U.S. corporate tax, ${ }^{4}$ these investments would usually be capitalized and deducted over time as they depreciate. Because a cash flow tax provides taxpayers with more generous deductions, it will generally raise less money than the U.S. corporate tax. The main empirical question this article seeks to answer is: How much less?

I find that, holding corporate behavior fixed, the actual tax raised only slightly more than the hypothetical cash flow tax over the most recent period from 1995-2013. The difference was about 4 percent on average. ${ }^{5}$

One important implication from this result is that capital owners appear to bear a large fraction of the corporate tax as it is currently constituted. This is because economic theory holds that corporate cash flow taxes are largely borne by capital owners and the results imply that today's actual tax behaves in practice much like a cash flow tax. Thus, the result suggests that capital providers are the primary beneficiaries of the large corporate rate cut in the 2017 Act.

\footnotetext{
${ }^{2}$ Expensing is scheduled to phase out slowly over 2023 to 2027 (IRC $\S 168(\mathrm{k})(6)$ ), but it is quite possible it will be made permanent prior to the scheduled phase out.

${ }^{3}$ The cash flow tax I construct has the same tax rate as prevailed from time to time under the actual U.S. corporate tax over the 1957 to 2013 period.

${ }^{4}$ Although the U.S. corporate tax is nominally an income tax (IRC $\$ 11$ ), many of its features-even before the 2017 Act provided full expensing for equipment-were more similar to a cash flow tax, making it in reality more like a hybrid tax than a pure income tax. For more discussion see Section III.
}

${ }^{5}$ This 4 percent figure is based on assumptions commonly utilized in the literature. More conservative assumptions yield 21 percent on average. 
This economic theory flows from the different tax bases of income and cash flow taxes. Corporate income taxes raise revenue from the normal return to capital-the return savers demand for the use of their funds for a period of time. This kind of return is thought to be the most easily distorted by taxation, and as capital flows out of the country to escape taxes on the normal return, those taxes are partly passed on to labor via lower productivity and lower wages. By contrast, by allowing for immediate deduction of investment, cash flow taxes exempt the normal return from tax. ${ }^{6}$ However, both types of taxes do raise revenue when corporations earn "supernormal" returns through monopoly power or some other nonreproducible advantage. Taxes on this income are less likely to be passed on to labor, however, because these economic rents are so profitable that investors will not respond to tax increases on them by shifting capital elsewhere.

The Treasury's most recent model of corporate tax incidence embodies this theory. It concluded that 100 percent of taxes on supernormal returns (i.e., 100 percent of cash flow taxes) are borne by capital owners, while 50 percent of the additional revenue raised by a corporate income tax from taxing the normal return to capital is passed on to labor (Cronin et al. 2013). ${ }^{7}$ Applying this model to my results suggests that only 2-10 percent of the corporate tax fell on labor over the primary study period. ${ }^{8}$ It also provides, as noted, a clear prediction of who will receive the lion's share of the benefit from the 2017 rate cut: capital providers. Indeed, the switch to full expensing of equipment as part of the 2017 Act will only reinforce this conclusion as it further pushes the U.S. corporate tax toward being like a cash flow tax and reduces revenue from the normal return. ${ }^{9}$

\footnotetext{
${ }^{6}$ The intuition for why the cash flow tax exempts the normal return is as follows: (1) cash flow taxes allow for the immediate deduction of the costs of investment long before any economic depreciation takes place; (2) this means the government in effect puts up a fixed percentage of the cost of investing and takes the same percentage of the cash flows; (3) this makes the government a full equity partner in the investment; (4) the private rate of return on projects earning the normal return is unchanged by having an additional equity partner; (5) which means the cash flow tax exempts the normal return.
}

${ }^{7}$ The Treasury unceremoniously removed the white paper describing the Cronin et al. model and data from its website in 2017 (Rubin 2017). The hasty removal of the paper, reminiscent of Roman damnatio memoriae, left a noticeable gap in the sequencing of the white papers on the website-now numbered $3,4,6$. The Treasury does not appear, however, to have published a new methodology for distributing the corporate tax burden. In the absence of another model and consistent with earlier drafts of this article, however, I continue to refer to the Cronin et al. model as the "Treasury Model."

As discussed below, the Treasury model's assumption that taxes on supernormal returns fall entirely on the owners of corporate capital is likely too extreme. Nevertheless, I employ this assumption in much of my analysis below, and one limitation of this paper is that I reserve for further research the important question of empirically testing that assumption in this context.

${ }^{8}$ I put aside the issue for now of whether the cash flow tax would also fall, in part, on the return to risk. To the extent it does, it would do so in the same manner as the actual corporate tax. Under the Treasury's model, taxes on the return to risk are also borne by capital owners (Cronin et al. 2013). I return to this question in greater detail in Section VII.

${ }^{9}$ In addition, my explanations for why the corporate tax raised so little revenue from the normal return are likely to apply to pass-through businesses as well. Thus, although I do not formally model it, it seems likely that the 20 percent Qualified Business Income Deduction (IRC $\$ 199 \mathrm{~A}$ ) will have similar incidence to the corporate rate cut, with the vast majority benefiting business owners rather than flowing down to employees of those businesses. 
A second important implication of my results is that the United States could switch fully and permanently over to a cash flow tax, which is likely to be administratively simpler for both the government and corporations, at relatively low revenue cost. For example, Treasury estimates that businesses spend over 450 million hours tracking and calculating depreciation, which would not be necessary under a cash flow tax (Treasury Department 2011). With these gains would come some new administrative problems, however, particularly with respect to financial services firms.

A third implication is that the impact of fully switching to a cash flow tax on the operations of the real economy and its efficiency are likely to be fairly small. This means, for example, that the 2017 Act's (supposedly temporary) switch to allowing expensing of equipment will have both smaller revenue consequences and will spur less new capital investment (a.k.a. "capital deepening") than many models predict. It is true that a permanent switch to a cash flow tax would fully equalize the treatment of debt and equity and would thus reduce the use of debt financing and make the economic system more resilient and less prone to financial crises (Schularick \& Taylor 2012). In addition, as discussed below, a cash flow tax would probably improve efficiency by equalizing the tax treatment of different industries regardless of whether they use primarily physical or intangible capital. Still, the relatively small difference in revenue raised by the hypothetical cash flow tax suggests that these gains will be more modest than is often asserted and buttresses contentions that administrative complexity should be a first-order priority when deciding whether to switch to cash flow taxation (Weisbach 2004).

The article then explores the reasons why the tax appears to have raised so little revenue from the normal return from 1995-2013. Almost certainly part of the explanation is the decline in the riskless normal return to capital-as proxied by the rate on Treasury bonds-during the second half of the period. Nevertheless, even during the mid-1990s when the risk-free rate was relatively high, only 20-30 percent of the tax was raised from the normal return, much less than one might have otherwise predicted. ${ }^{10}$ Another factor driving down the tax raised from the normal return is corporations' increasing investment in intangible capital. Investment in most kinds of intangible capital has always been immediately deductible, as would be true under a cash flow tax. Put differently, the corporate tax has always exempted the normal return associated with most intangible investments, but the share of (normal-return-exempt) intangible investments is growing rapidly. To really understand the role of these phenomena we need a much longer sample, however. I therefore supplemented the primary study period data by hand collecting tax return data going back to 1957 . I find that both decreases in the risk-free rate and increases in investment in intangible capital are associated with declines in the portion of the corporate tax estimated to be raised from the normal return.

\footnotetext{
${ }^{10}$ During this period, a tax at the statutory rate (35 percent) on the nominal risk-free normal return-as proxied by a 10-year Treasury-to the book value of equity in C-corporations would have yielded revenue equal to 70-80 percent of actual corporate tax collections. Likewise, a tax on the real risk-free normal rate of return would have raised about 50 percent of actual corporate tax revenue.
} 
The contribution of this article is twofold. First, it expands on the existing literature that creates hypothetical cash flow taxes to study how much tax is raised from the normal return-exemplified by Gordon et al. ("GKS") (2004b) —but applies that same methodology to a much longer sample from 1957 to $2013 .{ }^{11}$ This longer sample gives more reliable estimates to the more policy relevant 1995-2013 period, and allows a more systematic examination of the reasons for the low portion of the tax raised from the normal return.

Second, the article improves the GKS methodology and explores the impact of different assumptions used in past papers to understand how sensitive the results are to these assumptions. For example, all the past publications have (implicitly) relied on the assumption that capital investment grows at the rate of interest, and this article includes a novel adjustment for cases in which this assumption is violated. Likewise, the analysis bounds the effect of the nonrefundability of losses, which is not addressed in prior work, but that is potentially important; see Auerbach (2005). In addition, it analyzes how prior scholars' different treatments of amortizable and depletable capital, "bonus depreciation," and choice of summary statistics affect the results, thus reconciling the existing papers in the literature. It finds that using the original GKS assumptions yields a significantly lower portion of the tax estimated to be raised from the normal return (4 percent) compared to more recent papers using different assumptions (e.g., about 35 percent in Cronin et al. 2013).

Two limitations of this study should be noted. First, it is not clear that the assumption that 100 percent of taxes on supernormal returns stay with capital owners is justified. ${ }^{12}$ In fact, it is likely some of these taxes on rents will be shifted in the long run in an open economy (see Devereux \& Griffith 2003), although less than taxes on the normal rate of return. ${ }^{13}$ Because I nevertheless use this assumption, it pushes my results toward

\footnotetext{
${ }^{11}$ Most of the papers in this line, Gordon and Slemrod (1988), GKS (2004), and Gordon et al. (2004a), study a single year; Cronin et al. (2013) study a couple of years. Power and Frerick (2016) study 1991 to 2013.

${ }^{12}$ It is worth distinguishing here between true economic rents and so-called quasi-rents. Economic rents are payments to a factor of production, here capital providers, which exceed what is required to induce the provision of that factor. Some monopoly profits are quasi-rents, rather than true rents, however. For example, if a patent gives rise to the monopoly, the promise of these monopoly profits ex post may have been necessary to induce the initial investment. Hence from an ex ante perspective, these profits may not be true rents. The same is true of other expenses a firm may incur ex ante (employees' salary, market research, etc.) in trying to find positive net present value projects.

In a simple model, a cash flow tax will exempt quasi-rents, but not true rents from taxation. But if a firm cannot fully deduct its costs-for example because the founder puts in "sweat-equity" without drawing an (adequate) salary-this clean division between the cash flow tax's treatment of true and quasi-rents will break down. C-corps are dominated by large, highly liquid, publicly traded firms which reduces the importance of this issue, but does not fully erase it.
}

\footnotetext{
${ }^{13}$ The "incidence" estimated here, as in the Treasury model, is limited to estimating the distribution of the burden of taxes actually levied, and does not include an estimate of the size or distribution of the excess burden created by the corporate tax. Note, however, that the estimates suggest most of the tax is raised from inframarginal returns/economic rents or the return to risk. As discussed below, taxes raised from these sources should have relatively low excess burden.
} 
the tax falling on capital owners. ${ }^{14}$ Second, as noted above, the corporate tax is not fully refundable. When firms lose money, they receive net operating losses (IRC $§ 172$ ), which in practice are worth significantly less than their face value because some firms do not generate enough profits to use the offsets to reduce their current and future taxes. ${ }^{15}$ The insufficiency of loss offsets will make some of the existing tax and even a cash flow tax fall on the return to risk, and can make a cash flow tax actually fall partly on the normal return. ${ }^{16}$

The remainder of the article is organized as follows: Section II gives an introduction to corporate tax incidence analysis and modifications of the traditional models to analyze open economies and imperfect competition; Section III explains why a cash flow tax exempts the normal return, while an income tax does not; Section IV presents an approximate ceiling on the portion of the tax raised from the normal returnfinding it is as little as 15 percent over the most recent years-which helps confirm that the results in Section VI are reasonable; Section V describes how the hypothetical cash flow tax is constructed by replacing depreciation and amortization deductions with an immediate deduction for all new fixed investment and inventory, and by removing net financial income from the tax base; Section VI presents the primary results, showing that the cash flow tax would have raised only 4 percent less income than under the then current tax regime from 1995 to 2013; Section VII explores the implications of the results, including for the 2017 Act, and examines the reasons why the hypothetical cash flow tax and the actual tax raised similar amounts of revenue; Section VIII concludes.

\section{Literature}

In this section I briefly review the literature on corporate tax incidence, particularly highlighting the work underlying the Treasury model. These papers show: (1) in an open U.S. economy, labor likely bears a significant fraction of taxes on the normal return to capital, but (2) labor probably bears a much lower fraction of taxes on supernormal returns. I then discuss in detail the papers that have tried to decompose the corporate tax base into taxes on the normal return and supernormal returns by creating hypothetical cash flow taxes.

\footnotetext{
${ }^{14}$ If supernormal returns are significantly more internationally mobile than how I model them, the results still contain an important lesson. Because the results imply that the corporate tax base is largely risk/supernormal returns, the gains from international cooperation in combating profit shifting are proportionally larger and the scope for beneficial tax competition narrower. I thank Professor Dharmapala for making this point.

${ }^{15}$ The offsets are also neither indexed for inflation nor interest.

${ }^{16}$ In a robustness check, I find that my methodology could understate the amount of tax raised from the normal return by at most 10 percent because of the imperfectness of NOLs.
} 


\section{II.A. Harberger and Other Models of Corporate Tax Incidence}

The simplest model of corporate tax incidence concludes that the tax stays where it lands initially: on corporate shareholders in proportion to their ownership. ${ }^{17}$ Taxes frequently induce changes in behavior that shift the tax burden, however, and a more satisfying general equilibrium approach was proposed by Arnold Harberger in 1962. Harberger analyzed a closed economy, with perfectly competitive corporate and noncorporate sectors each producing a different good, and fixed economy-wide amounts of labor and capital that could move freely across sectors. By assuming perfect competition and constant returns to scale, Harberger's model precludes economic rents: all capital income is the normal return. Intuitively, the tax has two effects in this model. First, corporations switch from using capital to using labor, reducing demand for capital. This places a burden on capital owners by lowering the return to capital. ${ }^{18}$ Second, the cost of the good produced by corporations will rise, lowering demand, and shifting capital and labor out of the corporate sector. This shift can also change who bears the tax, and its impact depends on a number of parameters. ${ }^{19}$ Using reasonable estimates of these parameters, Harberger concluded that capital in fact bore the entire tax in the United States over the long term. $^{20}$

Countless modifications to Harberger's approach have been made, but the most relevant here are relaxing the assumption of a closed economy and no economic rents. The importance of modeling international trade and capital flows has grown significantly during recent years. ${ }^{21}$ If the assumption of no economic rents is retained, a Harberger-style model gives very different predictions when it is extended to a small open economy with perfectly mobile capital. As Roger Gordon and Jim Hines (2002) summarize:

\footnotetext{
${ }^{17}$ As Auerbach (2005) observed, the direct ownership analysis is still useful because changes in the corporate tax often burden the owners of existing corporate capital in ways that cannot be shifted, particularly in the short run.

${ }^{18}$ In this model, a tax on corporate capital's income will cause capital to flow out of corporations into the non-
corporate sector. This in turn drives down the return to capital in the noncorporate sector until it is equal to the
after-tax return in the corporate sector. Thus, in the long run, the burden on corporate capital owners-if there is
any-must be the same as for owners of noncorporate capital because each will earn the same amount after taxes.
}

${ }^{19}$ Namely, the second effect depends on the relative capital intensity of the corporate and noncorporate sector, the elasticity of substitution between capital and labor in each sector, and the elasticity of demand for the goods produced by the sectors.

\footnotetext{
${ }^{20}$ The Treasury model is confined to long-term incidence and so I also put aside questions about the tax burden during the transition to the long-run outcome. Readers should note, however, that the transition period can be quite important. With respect to the rate cut in the 2017 Act, for example, the immediate beneficiaries are corporate capital owners and so, if anything, here the transition period should favor capital owners more than the longterm incidence.
}

\footnotetext{
${ }^{21}$ For example, from 1987 to 2003 the value (at current cost) of private fixed capital in the United States grew at 5.3 percent per year from $\$ 10.7$ trillion to $\$ 24.8$ trillion, while U.S.-owned assets abroad grew at 11 percent per year from $\$ 1.4$ trillion to $\$ 7.4$ trillion and, likewise, foreign-owned U.S. assets grew by 11.5 percent per year from $\$ 1.4$ trillion to $\$ 8.2$ trillion (Auerbach 2005).
} 
In a small open economy a tax on the return to domestic capital has no effect on the rate of return available to domestic savers since the domestic interest rate is determined by the world capital market. Domestic investment falls in response to higher tax rates. For firms to continue to break even, in spite of the added tax, either output prices must rise or other costs must fall by enough to offset the tax. When output prices are fixed by competition with imports, the tax simply causes the market-clearing wage rate to fall. As a result, the burden of the tax is borne entirely by labor or other fixed domestic factors.

Of course, actual conditions differ quite a bit from this model. The United States is not a small economy whose policies will only negligibly affect world interest rates and goods prices. Moreover, capital is not perfectly mobile and the goods produced in the United States are not perfectly substitutable for those produced abroad.

Depending on how they account for these complications, scholars have reached varied conclusions on who bears the burden of a corporate tax on the normal return to capital in an open U.S. economy. For example, Jennifer Gravelle (2013) summarizes four of these studies, with one finding that as much as 70 percent of this tax is borne by labor. She observes that the studies with the largest estimates of labor's burden do not account for at least one of the complexities discussed above. She argues that using the best estimates of limits on capital mobility, international product substitution, and the traditional parameters involved in the Harberger model, all of the studies would yield roughly that 40 percent of the U.S. corporate tax is borne by labor and 60 percent by capital. Citing Gravelle's study and others like it, the Treasury model concludes that 50 percent of the U.S. corporate tax on the normal return is borne by U.S. labor (Cronin et al. 2013).

A variety of other studies have attempted to use cross-sectional and/or longitudinal variation in corporate tax rates across countries to understand corporate tax incidence directly rather than in a Harberger-type model, but have reached vastly different conclusions ranging from labor bearing almost none of the tax (Clausing 2013) to 60 percent (Desai et al. 2007) and even in some papers well over 100 percent. This divergence is in large part, as Alan Auerbach (2018) observes, due to the difficulty of identifying "credible natural experiments for corporate tax reforms or to control for the many developments occurring within countries at the same time as corporate tax changes." 22

\section{II.B. Taxing Economic Rents}

Like adding the effect of international trade, relaxing Harberger's assumption of no economic rents appears to be increasingly important in analyzing the U.S. corporate tax burden. In a closed economy, with neoclassical production functions and savings behavior,

\footnotetext{
${ }^{22}$ Within-country studies are likely to be more reliable, but are not likely to be an accurate gauge of incidence at the national level because capital flows much more easily across states or across U.S. industries than from the United States to other countries. Suárez Serrato and Zidar (2016) create a structural model and find that state corporate taxes are borne about 30 percent by labor. It is tempting to think of this 30 percent estimate-if correct about state-level corporate taxes-as an upper bound on labor's share of the U.S. corporate tax, in a context where capital mobility is more limited. The results there are somewhat at odds with Suárez Serrato (2018), who finds large domestic employment and wage effects from reducing the ability of U.S. multinationals to use Puerto Rico as a tax haven.
} 
a tax on these rents is nondistortionary and has traditionally been found to be borne by the owners of corporate capital. ${ }^{23}$ Intuitively, investors will still invest in rent-earning assets, which, even after taxes, earn more than the normal return. Therefore, the amount of capital invested and the allocation of that capital will not change if a tax on rents is introduced or increased. Taxing these rents imposes no excess burden regardless of whether they result from declining returns to scale in a competitive market or from market power held by firms with nonreproducible advantages like brand names, know-how, or other intellectual property. Following these studies, the Treasury model concludes that 100 percent of taxes falling on economic rents stick with capital owners. ${ }^{24}$

Moving to an open economy complicates the question of who bears taxes on rents. Some economic rents earned by U.S. corporations are closely tied to the United States either because of natural resources or other immobile productive factors (e.g., key employees who will not move or agglomeration economies like Silicon Valley). The effect of taxing these rents is covered by the traditional analysis described above. Other rents, however, are firm specific, like brand names, and may allow the firm to earn supernormal returns wherever it chooses to produce. Taxing these rents may reduce domestic investment as firms move production abroad to escape the rents tax. ${ }^{25}$ This will lead to American labor bearing some of the tax on these rents, for the same reason as with taxes on the normal return in the open economy Harberger-style models discussed above.

\footnotetext{
${ }^{23}$ Fane (1984), in response to Feldstein (1977), points out that for a tax on rents to be borne entirely by the rentiers, it must be analyzed "follow[ing] 'the traditional practice in incidence analysis' of considering compensated taxes." I follow this assumption here.

In reality, of course, it is likely that this assumption does not hold, making a tax on rents accruing to the owners of corporate capital, equivalent to a compensated tax along with a lump sum transfer away from those owners. This transfer can affect relative prices, in turn affecting the ultimate incidence of the tax. Fane observes, however, that in many models "lump-sum redistributions of income do not affect relative prices. Even when they do, the incidence effect is often small relative to the size of the redistribution." Nevertheless, an additional avenue for further research would be to calibrate a model with representative agents to help us understand whether less (or indeed more) than $100 \%$ of an uncompensated tax on rents accruing to the owners of corporate capital is borne by those owners through price adjustments.
}

\footnotetext{
${ }^{24}$ Even in a closed economy, more complex models sometimes shift the burden of compensated rents taxes off the owner of the rent-producing asset or find that a rents tax could be somewhat distortive. For example, "where investors must either commit a large chunk of capital or none at all ... taxes on pure rents may affect both the composition and level of investment" (Hines et al. 2010). In addition, in more complicated models of imperfect competition, taxes on rents may also affect the size of the rents extracted (Davidson \& Martin 1985; Liu \& Altshuler 2013). There may also be "rent sharing," which allows labor to capture some economic rents that might otherwise flow to capital owners. For example, high union wages in the auto industry from roughly 1950 to 1980 are usually interpreted as rent sharing; see Alder et al. (2017). In these cases, corporate taxes on economic rents may reduce the rents shared with labor and thus such taxes would fall in part on employees of the firm. This may be true at the very high end of the wage scale as well because CEO compensation is likely partly rent sharing (Piketty et al. 2014). Card et al. (2016) survey the rent-sharing literature in labor economics and find an elasticity of quasi-rents to wages of $0.05-0.15$.
}

${ }^{25}$ In theory, this incentive should be partially blunted by the provisions related to Global Intangible Low-Taxed Income (GILTI) in the 2017 Act. 


\section{II.C. Estimating the Portion of Corporate Taxes Raised from the Normal Return}

Because of the different effects of taxing the normal return and supernormal returns, it is important to understand how much of the corporate tax is raised from each. There is a small body of literature doing this, which was pioneered by Roger Gordon and Joel Slemrod (1988). They analyzed data from 1983 and concluded, holding fixed behavior, that a cash flow tax that exempted the normal rate of return would actually have raised more money than the existing tax, and thus that no money was raised that year from the normal return by the corporate tax. Gordon et al. (2004b) ("GKS") performed a similar calculation on data from 1995 and concluded that moving to a cash flow tax would reduce corporate tax revenue by 16 percent. $^{26}$

In 2013, Julie-Anne Cronin, Emily Lin, Laura Power, and Michael Cooper of the Treasury's Office of Tax Analysis (OTA) - using somewhat different assumptions from GKS and data from 1999-2001, 2004, and 2007-concluded that 37 percent of the tax fell on the normal return. Until 2017, the Treasury distributed the corporate tax burden using this analysis, assigning 18 percent ( 37 percent times 50 percent) of the tax to labor. Most recently, Power and Frerick (2016) used the Cronin et al. methodology to examine 1991-2013 and find that supernormal returns as a portion of taxable income are increasing over the period, ranging from 60 percent at the start of the period to 75 percent at the end. As discussed in detail below, most of the differences between the GKS results and those of Cronin et al. are attributable to the assumptions used in calculating the changes needed to construct a cash flow tax and which summary figure the authors use to approximate the portion of the tax raised from the normal return.

\section{Cash Flow Taxation as a Tax on Economic Rents}

In Section I, I asserted that income taxes raise revenue from both the normal return to capital and supernormal returns. I claimed that a cash flow tax, by contrast, exempts the normal return and raises revenue only from supernormal returns. It thus does not distort marginal investments. This distinction between cash flow and income taxes underlies the GKS method I use in this article and as such I explore the intuition and mathematical underpinnings in more detail in this section. ${ }^{27}$ Many readers, however, are familiar with these results. Those readers should feel free to skim this section.

\footnotetext{
${ }^{26}$ Gordon et al. (2004a) also make a similar calculation for 2004, but using 2000 data adjusted for changes in profits and investment, finding switching to cash flow tax would have lowered revenue from nonfinancial C-corps by $\$ 55$ billion. Laura Kalambokidis's (unpublished 1991) dissertation examines the period from 1975-1986 using somewhat different assumptions.

${ }^{27}$ All the models discussed are highly stylized. They provide a background for understanding how constructing a hypothetical cash flow tax can help separate how much of the current tax is raised from the normal return to capital. I reserve until later a discussion of how additional complexities, most importantly, risk and the absence of fully refundable tax losses, affect my conclusions.
} 
A firm will invest in any project in which the project's (properly discounted) income stream meets or exceeds its cost. For the moment, assume that there is no risk and no taxation. Let us also assume that a project will end in year $\mathrm{T}$ and be worthless at that point, and the project costs $\$ 1$, all paid in period 0 , and $\mathrm{e}_{1} \ldots \mathrm{e}_{\mathrm{T}}$ is the stream of income the project produces, and $r$ is the risk-free discount rate. The firm (or representative shareholder) will invest if $\sum_{t=1}^{T} \frac{e_{t}}{(1+r)^{t}} 1$. The lowest value project the firm will be willing to invest in earns $\sum_{t=1}^{T} \frac{e_{t}}{(1+r)^{t}}=1$. Such a project is worth exactly the opportunity cost of the project, which is lending at the risk-free rate, $r$. This is the "marginal" project if the firm has many projects to choose from. Note that in a perfectly competitive world with constant returns to scale, all the projects a firm can invest in will be like the marginal project, in which the return on the project is exactly equal to its costs. This means that there are no economic rents.

Moving out of the tax-free world, it has long been understood that under certain conditions, a tax on real cash flows does not distort marginal investment decisions (Brown 1948). Such a tax gives an immediate deduction for the full cost of the project in period 0 and no depreciation deductions are available later. Assuming the tax is refundable, or that the firm has other income to be offset by the deduction, the firm's marginal investment decision looks exactly as it did in the world where taxes were ignored. Intuitively, if $\tau$ is the tax rate, the government becomes a full partner in the project by providing $\tau$ percent of the initial capital investment and taking $\tau$ percent of the earnings in all later periods. This means the firm's rate of return does not change. ${ }^{28}$

More formally, earnings in each period are reduced by $\tau \cdot e_{t}$, where $\tau$ is the tax rate, but the cost of the initial investment is also reduced by $\tau$. Thus after-tax earnings are $\sum_{t=1}^{T} \frac{e_{t}}{(1+r)^{t}}(1-\tau)$, while the cost of the project is now $(1-\tau)$. Hence for the marginal project, the firm's calculus is the same after taxes as without taxes because the after-tax earnings on the marginal project are exactly equal to its after-tax cost: $\sum_{t=1}^{T} \frac{e_{t}}{(1+r)^{t}}(1-\tau)=(1-\tau) \leftrightarrow$ $\sum_{t=1}^{T} \frac{e_{t}}{(1+r)^{t}}=1$. Note that the government raises no revenue from this tax in real terms on marginal projects, which earn, $r$, the risk-free rate. The government gives a subsidy of $\tau$ and over time collects revenue with a present value of $\tau .^{29}$ Thus the normal, risk-free return to capital is untaxed under a cash flow tax. If the project will earn an economic

\footnotetext{
${ }^{28}$ This result can also be thought of as involving a "gross up" where the immediate deductibility of investment allows a firm to invest $\tau$ more than it could originally, and this second investment generates a subsidy of $\tau^{2}$ and so on, which, when the infinite stream is summed, equals $\frac{1}{(1-\tau)}$. Such a subsidy is assumed to be put into marginal projects since all rent-producing projects will have already been fully exploited.
}

${ }^{29}$ Recall that the present value of the earnings stream for the marginal project is 1 . The government receives $\tau$ percent of those earnings in each period through the tax. The tax revenue thus has a present value of $1 \cdot \tau$. 
rent such that $\sum_{t=1}^{T} \frac{e_{t}}{(1+r)^{t}}=1+n$, the government will collect $\tau \cdot \mathrm{n}$, where $\mathrm{n}>0$ is the value of the economic rent. Government revenue is worth, in present value, $\tau \cdot(1+n)$ and it provides a subsidy of $\tau$. Firms will still invest in all such rent-earning projects, however, because, after taxes, the projects still have a positive net present value.

Unlike a cash flow tax, an income tax requires firms to gradually write off assets that last longer than one year. These long-lived assets include fixed capital goods like equipment and structures. In addition, payments for training employees, executives engaged in long-term strategy, $\mathrm{R} \& \mathrm{D}$, development of customer relationships, advertising, and other ways of building goodwill will benefit the firm over a period of multiple years and would be deducted over time under an ideal income tax. Nevertheless, these expenses are immediately deductible in full under the actual corporate tax both during the primary study period and under the 2017 Act. $^{30}$

Capitalized assets do eventually stop producing income for the firm and thus decline in value over time. We can represent this yearly depreciation by comparing the change in the value of the project in year $t$ relative to its value in the previous year. In symbols: Depreciation $t_{t}=V_{t}-V_{t-1}$, where $V_{t}$ is the project's value in period t. ${ }^{31}$ In equilibrium, the value of holding onto the project for another period must match the value of selling the project and investing in the safe asset. Thus $(1-\tau) \cdot\left(e_{t}+V_{t}-V_{t-1}\right)=r V_{t-1}$. Note, here $\mathrm{r}$ is now the after-tax risk-free rate. Given that $\mathrm{V}_{\mathrm{T}}=0$, this implies $(1-\tau)$. $\left(\mathrm{e}_{\mathrm{t}}+0-\mathrm{V}_{\mathrm{T}-1}\right)=\mathrm{rV}_{\mathrm{T}-1}$, which can be rewritten as $\mathrm{V}_{\mathrm{T}-1}=\mathrm{e}_{\mathrm{T}} /\left(1+\frac{r}{(1-\tau)}\right)$. Repeating this process backward, we can write the value in any period $0 t T$ as:

$$
V_{t}=\frac{e_{t+1}}{1+\frac{r}{(1-\tau)}}+\ldots \frac{e_{T}}{\left(1+\frac{r}{(1-\tau)}\right)^{T-t}}
$$

Thus, the firm will use $\frac{r}{(1-\tau)}$ as its discount rate (or cost of capital) and the marginal project under the income tax must earn on average a return of $\frac{r}{(1-\tau)}$ because the income tax taxes the risk-free rate of return. Like a cash flow tax, however, an income tax also taxes rents at a rate of $\tau$ per dollar of rents.

In reality, the U.S. corporate tax both during the period of study and today is a hybrid of an income tax and a cash flow tax because it allows companies to expense a portion or all of the purchase price of many long-lived assets, rather than requiring them to fully capitalize the assets. As discussed below, $\mathrm{R} \& \mathrm{D}$, payments to executives to engage in long-term planning, advertising and other expenses which build goodwill, and employee training probably exceed 50 percent of total business investment in long-lived assets, yet are immediately expensed under the Code. In addition, in order to encourage

\footnotetext{
${ }^{30}$ It should be noted that the 2017 Act provides that beginning in 2022 R\&D expenses will be amortized over a five-year period rather than expensed.

${ }^{31}$ Ignoring taxes, for any period $\mathrm{t}$, the value of the project can be written as $V_{t}=\frac{e_{\ell+1}}{1+r}+\cdots \frac{e_{T}}{(1+r)^{T-t}}$.
} 
investment, Congress provided for "bonus depreciation" for 12 of the final 16 years before the 2017 Act took effect. This allowed firms to immediately expense 30-100 percent of the purchase price of qualifying equipment, depending on the year. The 2017 Act in turn provides for an immediate 100 percent deduction for equipment purchased until 2022, with a scheduled phase out over several years after that (IRC $§ 168(\mathrm{k})$ ). ${ }^{32}$

Under such a hybrid system, the firm's discount rate and cost of capital will be $\frac{r}{(1-\sigma \tau)}$, where $(1-\sigma)$ is the fraction of the project initially expensed, and the firm is allowed to take $\sigma$ percent of the economic depreciation as a deduction thereafter. ${ }^{33}$ This has the effect of roughly exempting $(1-\sigma)$ percent of the normal rate of return from tax. Intuitively, it can be thought of as allowing $(1-\sigma)$ percent of any investment to be taxed under a cash flow regime, while the remaining $\sigma$ percent of the project is taxed using an income tax. Rents are still taxed at $\tau$ since both types of taxes raise $\tau$ per dollar of economic rents. As the fraction initially expensed goes to 1 , the tax system converges to the cash flow outcome.

I turn now to empirically estimating how much of the corporate tax is raised from the normal return to capital. The main results in this article use the GKS method, but before getting there I present an approximate ceiling on the percent of the tax raised from the normal return. This analysis shows that during the first half of the primary study period ending in 2003, the normal return made up an important potential part of the corporate income tax base, but by the second half (2004-2013) it was pretty small. Indeed, even with a pure income tax that, unlike the actual tax, captured 100 percent of the real normal return in the tax base, the normal return would have made up only about 15 percent of the actual tax base over this period. This helps confirm the reasonability of the estimates in Part VI and demonstrates that declines in the normal return likely drive some of the main results.

\section{How Much of the U.S. Corporate Tax was Raised from the Normal Return to Capital? An Approximate CeILING}

Over the last 20 years both the nominal and real risk-free rate have declined substantially, without a matching decrease in corporate income. Thus, even if the U.S. corporate tax was a pure income tax, the portion of corporate tax revenue raised from the normal return to capital would have fallen.

I illustrate this point in Figure 1, which shows how much an ideal income tax would raise from the normal riskless rate of return for nonfinancial C-corporations and

\footnotetext{
${ }^{32}$ Even without bonus depreciation or full expensing of equipment, the Code's standard depreciation system (MACRS) is designed to allow firms to recover depreciation deductions faster than economic depreciation takes place (Margalioth 2007).

${ }^{33}$ The derivation is more complicated than for a pure income tax and I do not show it here. A full exposition can be found in Auerbach (1983).
} 
Figure 1: Corporate taxes on nonfinancial C-corps versus tax on normal rate of return.

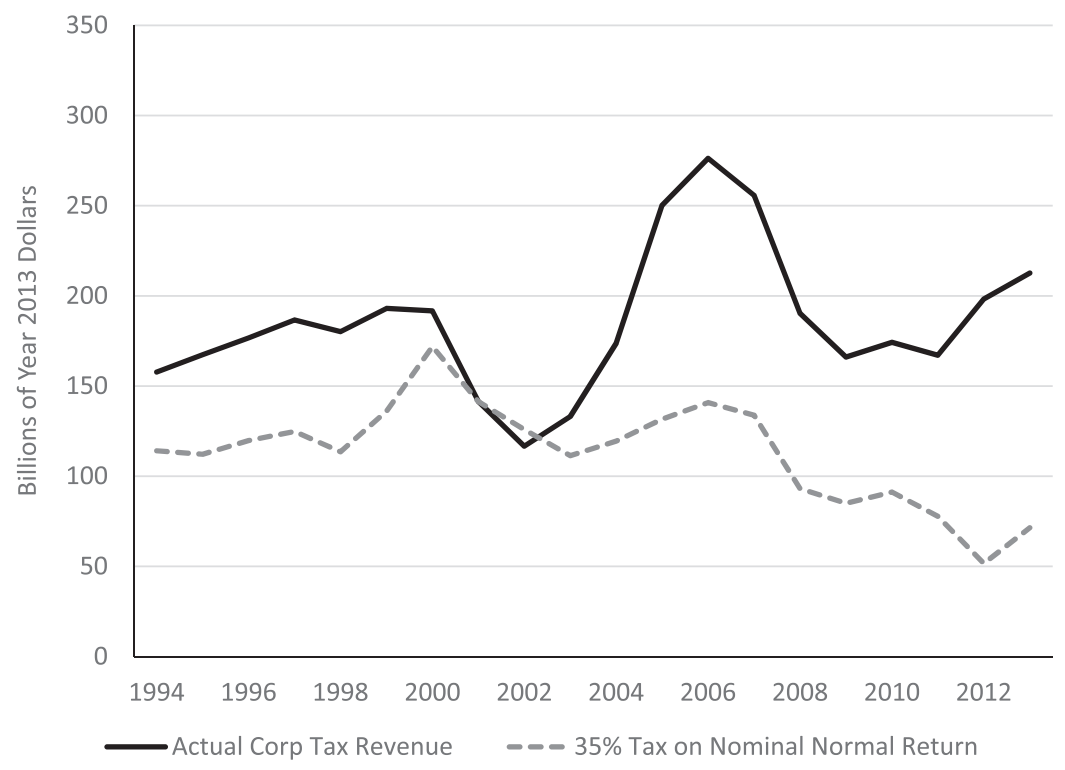

compares this with actual corporate tax revenue from these firms from 1994 to 2013. More specifically, Figure 1 uses the book value of nonfinancial C-corporations reported to the IRS and multiplies it by the nominal risk-free rate, as proxied by the yield on 10-year Treasuries, and then by the then applicable 35 percent tax rate and compares it to actual corporate tax receipts. ${ }^{34}$

During the first half of the period (1994-2003), a 35 percent tax on the nominal normal return would have made up, on average, 79 percent of the actual corporate tax raised. During the second half (2004-2013), it would have composed 48 percent. The average over the full period was 64 percent. The decline in the importance of the normal rate of return is even more apparent using the real, instead of the nominal, return. The relevant figures are 46 percent for the first half and 15 percent for the second. Although these are quite rough approximations, they give us a sense of the upper bound for how much more the actual tax might raise than a cash flow tax because, contrary to the

\footnotetext{
${ }^{34}$ Details of the calculation are discussed in the Appendix, Table A-1. The choice of 10-year Treasuries, rather than a shorter maturity, follows Gentry and Hubbard (1997)—whose analysis was originally used in the Treasury model-but arguably overstates the potential role of the risk-free normal return because bonds of that length will include an important premium for inflation risk. On the other hand, the shorter maturity Treasuries probably understate the normal return because they function like money, which drives their returns below the normal return to capital (Krishnamurthy \& Vissing-Jorgensen 2012). In Appendix Table A-2 I replicate Gentry and Hubbard's own approximation of how much corporate income came from the normal return, which yields an average of 34 percent over 1995-2013, and 29 percent over 2003-2013.
} 
assumption in Figure 1, the actual tax captured well less than $100 \%$ of the normal return. In addition, the analysis helps us see how the importance of the normal return has declined over the last 20 years.

I turn now to the methodology underlying the main results and then to presenting those results.

\section{Creating a Hypothetical R-Base Cash Flow Tax- MeTHODOLOGY}

One way to implement a cash flow tax is to levy a tax on the firm's cash flow in real transactions, while ignoring financial transactions for tax purposes. This is an "R-base" tax as outlined in the Meade Report of 1978. Under such a tax, businesses can immediately deduct all real expenses, but cannot deduct interest or dividends paid. On the other hand, firms do not include interest or dividends received in gross income. All the most recent attempts to measure how much the corporate tax raises from the normal return to capital (GKS 2004; Cronin et al. 2013; Power \& Frerick 2016) construct an R-base and I do the same. Moreover, 2017 Act creates a R-base variant with immediate expensing of most physical capital and some limits on interest deductibility. ${ }^{35}$ Although an R-base tax has the advantage of simplicity, it provides no easy way to tax financial intermediaries because most of the revenue that these firms collect for their services is embedded in financial flows. Therefore, like GKS and Cronin et al., I confine my attention to nonfinancial corporations. ${ }^{36}$

I start by applying the same assumptions GKS used, but extending their analysis over the 1957-2013 period using aggregate tax data. Although I use GKS assumptions, I do not use the same summary measure of the portion of the tax raised from the normal return. Instead, I use the measure from Cronin et al. to make my results comparable to those used in the Treasury model. This figure measures the change in revenue associated with expensing productive capital (except land) divided by the total taxable income generated by real activities:

$$
\% \text { Tax Raised from Normal Ret. }=\frac{\text { Deprec }_{t}+\text { Amort }_{t}+\text { Depl }_{t}-\text { New Invst }_{t}-\Delta \text { Inventory }_{t-1, t}}{\text { Taxable Income }_{t}-\text { Net Fin Inc }_{t}}
$$

This proxy is adapted from Toder and Reuben (2007), and is designed to roughly account for both debt- and equity-funded corporate projects, without having to explicitly

\footnotetext{
${ }^{35}$ Unlike the R-base tax modeled here, even under the 2017 Act, the corporate tax continues to allow substantial interest deductibility, to tax net interest received, to tax some dividends received, and to require capitalization of inventory and structures.

${ }^{36}$ One way to deal with the problems raised by financial firms is to tax all businesses on real and financial cash flows, known as a $\mathrm{R}+\mathrm{F}$ base rather than on an R-base (for a proposal to use an $\mathrm{R}+\mathrm{F}$ base for all businesses, see Auerbach 2010). Or an R $+\mathrm{F}$ base could be used only for financial firms (Cunningham \& Engler 2012). The effect of moving to such a tax cannot be calculated from public tax data, however.
} 
examine how interest paid by corporations to individuals or partnerships (or financial corporations) is taxed. It can be thought of as an estimate of the portion of the current tax that would be raised from the normal return if all corporate projects were entirely equity funded and corporations had no net financial income. ${ }^{37}$ The downside of using this figure is that the "base" it uses in the denominator may be quite different from the actual tax base. For example, the corporate tax places no or often a negative burden on debt-funded projects with noncorporate lenders (Auerbach 2018), but these projects are given equal weight with equity-funded projects in this proxy. In Appendix Table A-3, therefore, I also present figures based on the estimate of the change in revenue from shifting to the R-base tax divided by the current amount of tax revenue raised, which is the summary figure used in GKS.

To calculate the numerator of Equation (1), I replace depreciation, amortization, and depletion deductions-the corporate tax code's mechanisms for the gradual cost recovery for capitalized assets-with immediate expensing of all new fixed investment. ${ }^{38}$ In addition, I allow firms to immediately expense the cost of producing inventory. Under existing law, inventory is capitalized until sold.

In adding these new deductions for immediate expensing and eliminating deductions associated with gradual cost recovery, the methodology makes no distinction between firms with positive net income and "deficit firms" (i.e., those with losses). In other words, giving a deficit firm a new deduction is treated the same way as giving a new deduction of the same size to a firm with net income, and vice-versa for removing existing deductions for gradual cost recovery. This can cause the methodology to over- or understate the effect of switching to expensing on actual tax revenues in a world without full refundability. ${ }^{39}$

To calculate the denominator of Equation (1), I remove from the existing tax base net financial flows: by (1) removing taxable interest received from the base, (2) adding interest deductions back to the base, and (3) removing domestic dividends. ${ }^{40}$ Following Cronin et al., I also remove all foreign dividends, including constructive dividends from controlled foreign

\footnotetext{
${ }^{37}$ Holding fixed behavior, GKS look at both the change in revenue of implementing an R-base corporate tax and from shifting individual income taxation to a consumption tax. Because GKS examine both the corporate and the individual side, they can control for the net effect of not taxing the normal return at either the corporate or individual level. Using the GKS measure but looking at only the corporate tax will miss tax placed on the normal return to corporate projects through taxing interest paid by corporations to individuals and partnerships. Nevertheless, because many lenders to corporations are either untaxed or tax preferred (pension funds, retirement accounts, charitable institutions), this will often be a low tax.
}

\footnotetext{
${ }^{38}$ I measure new fixed investment using BEA Table 4.7, which gives estimates for investment in structures and equipment for nonfinancial corporations. For more details, see Appendix Table A-3.

${ }^{39}$ If, on net, new deductions are disproportionately concentrated in deficit firms, then my methodology will likely overstate the cost of switching to expensing in terms of tax revenue. In fact, deficit firms seem likely to receive a slightly disproportionate share of new expensing deductions. For example, depreciation made up 2.6 percent of deductions of firms with net income, but 3.5 percent of deductions in deficit firms in 2013. On the other hand, as discussed below, deficit firms present a problem for expensing because imperfect loss offsets can cause even a cash flow tax to fall partially on the normal return to capital.
} 
corporations, from the tax base. ${ }^{41}$ Finally, I remove all capital gains and losses as well as other gains and losses to mimic the null tax effect of sales of used assets under a cash flow tax. ${ }^{42}$

\section{Results}

Figure 2 displays the main results showing the low percentage of the tax raised from the normal return. Using the GKS assumptions (the solid line with square markers), and holding fixed behavior, the average portion of the corporate tax raised from the normal return is just 4 percent over the 1995-2013 period.

The periods during which the line is positive indicate that the estimated cash flow tax would raise more money than the existing tax. This can happen during poor economic times when businesses run down inventory (generating larger inventory deductions than immediate expensing of inventory) and bonus depreciation reduces or eliminates the difference between cash flow and actual tax treatment of new equipment investment. ${ }^{43}$ The other two lines represent cumulative steps in moving toward the Cronin et al. assumptions. Adjustment 2 includes the previous adjustment.

Adjustment 1 (the dotted line) does not remove depletion and amortization deductions in moving to the R-base tax. The average portion of the tax raised from the normal return under this assumption is 21 percent. This roughly follows what Cronin et al. do: they retain depletion for taxing natural resource extraction and make only small changes for expensing what are now amortizable assets. ${ }^{44} \mathrm{GKS}$, by contrast, assume that no additional adjustment must be made to the investment figures to accurately proxy investment in new depletable or amortizable assets. There are advantages to each approach.

Intangible assets typically need be capitalized and recovered through amortization only when they are purchased from third parties (Kahng 2014). Thus, these assets can be thought of like sales of "used" physical capital assets and dealt with, as discussed above, by eliminating all capital gains. In addition, amortization includes some physical assets-

\footnotetext{
${ }^{41}$ The empirical importance of profit shifting out of the United States is hotly contested; see Dharmapala (2014). Nevertheless, taking a semi-elasticity with respect to tax rate differentials of 0.8 , profit shifting out of the United States and into foreign affiliates will significantly bias down my measure of the denominator of Equation (1)—taxable income from real activities conducted (directly) by U.S. C-corporations. As a result, if anything, the estimates in Section VI of the tax raised from the normal return are probably too large because the denominator of Equation (1) is too small.
}

\footnotetext{
${ }^{42}$ Under a cash flow tax, the sale of used assets is immediately taxable in full to the seller, but the buyer receives an immediate deduction, with exactly offsetting consequences if both firms are taxable corporations with net income. Thus, expensing all new investment and eliminating all capital and noncapital gains should lead to the same outcome as expensing both new and used assets and including the sale of used assets in the seller's taxable income. I use the first strategy. Note, however, that this can create problems for sales of used assets into and out of the corporate sector. For more detail, see Appendix Table A-3.
}

${ }^{43}$ I use a five-year running average to make the patterns on the graph easier to view, but this decision makes poor economic conditions take a number of years to fully materialize in the figure.

\footnotetext{
${ }^{44}$ Cronin et al. expense assets amortizable under Section 197 (acquired intangibles) and software.
} 
Figure 2: Portion of corporate tax lost switching to cash flow taxation, 1995-2013.

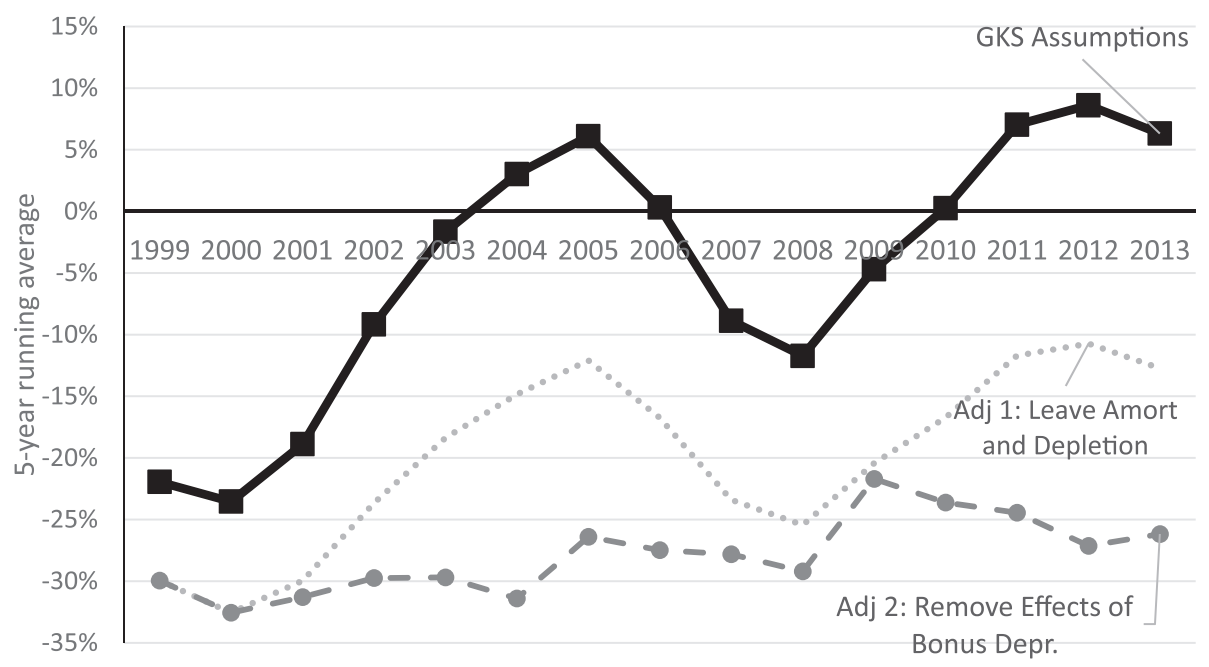

Notes: See Appendix Table A-3 for details on calculations.

for example, IRC Section 169 (pollution control devices) and Section 1400I (structures in revitalization neighborhoods) - which are covered in the investment data. In these cases, eliminating the associated amortization deductions is the appropriate treatment. Likewise, for depletion, depletable exploration costs are already covered in the investment data. Moreover, firms that use percentage depletion may take a deduction that exceeds their basis in the property and thus can be more favorable than expensing. ${ }^{45}$ These arguments favor removing amortization and depletion in calculating the shift to the R-base as GKS do. On the other hand, the Cronin approach is more conservative, largely leaving amortization and depletion in place where the initial investment associated with those deductions cannot be calculated reliably enough from the tax data.

Second, Cronin et al. strip out the effect of "bonus depreciation." I have roughly made this calculation in Adjustment 2 (the dashed line with circular markers). ${ }^{46}$ Reasonable minds can differ here, but I believe not trying to remove the effects of bonus depreciation is the better choice. By allowing the immediate expensing of a large portion of the purchase price of many long-lived physical assets, bonus depreciation made the tax during the

\footnotetext{
${ }^{45}$ The Treasury estimates that "excessive" percentage depletion was a roughly $\$ 1.6$ billion tax expenditure for corporations in 2013 (Treasury Department 2013). In total in 2013, depletion shielded at most $\$ 8.9$ billion of wouldbe tax revenue ( $\$ 25.4$ billion of depletion deductions times the 35 percent tax rate). This suggests that depletion is more favorable than expensing if the risk-free interest rate is at most 3 percent and the average resource is fully depleted within 12 years, which seems likely.
}

${ }^{46}$ I assume that the average MACRS depreciation length for all bonus depreciation eligible equipment is seven years as in Cronin et al. (2013). 
primary study period much closer to a cash flow tax and this will affect the distribution of the tax burden. Given that we had bonus depreciation for 12 of the 16 years prior to the passage of the 2017 Act and now have full expensing until 2022, some form of highly accelerated depreciation seems like the baseline even for long-term distribution of the tax burden.

One potential complication-as observed in Slemrod (2007) - is that the method of comparing the actual tax to a hypothetical R-base tax to understand the tax placed on the normal return to capital relies on the corporate capital stock growing at the rate of interest. If capital grows slower than the rate of interest, the method will understate the portion of the tax raised from the normal return and vice-versa if corporate capital is growing more quickly than the risk-free interest rate. Putting aside operating deductions, recall that deductions under a pure income tax will be $\delta_{t} \mathrm{~K}_{t-1}$, where $\delta_{t}$ is the average economic depreciation of corporate capital in period $t$, and $\mathrm{K}_{\mathrm{t}-1}$ is corporate capital in the prior period. Under the cash flow tax, the relevant deductions are equal to new capital purchased in period $t, I_{t}=\left(\delta_{t}+\alpha_{t}\right) K_{t-1}$, where $\alpha_{t}$ is the growth rate of corporate capital in period t. For the difference between the cash flow and income taxes to be the tax on the normal return to capital, $\alpha_{t}$ must equal $r_{t}$, where $r_{t}$ is the normal risk-free return.

In the extreme, we can see the potential for understatement by imagining a corporate income tax in a risk-free world, in which all corporate projects are equity funded, earn on net the normal return, $\mathrm{r}$, and $\mathrm{K}_{\mathrm{t}}$ depreciates at rate $\delta$, but $\alpha_{\mathrm{t}}=0$ and thus $\mathrm{K}_{\mathrm{t}}=\mathrm{K}_{\mathrm{t}-1}$ because $\mathrm{I}_{\mathrm{t}}=\delta \mathrm{K}_{\mathrm{t}}$ ${ }_{-1}$. In this world, the corporate income tax imposed in period $t$ will raise $\tau \cdot r \cdot \mathrm{K}$ and 100 percent of the tax is raised from the normal return. Applying the GKS method outlined above, however, to period $\mathrm{t}$ will yield that 0 percent of the tax comes from the normal return because new investment $I_{t}$ exactly equals economic depreciation allowed by the income tax $\left(\delta \mathrm{K}_{\mathrm{t}-1}\right)$, and hence the cash flow tax would raise exactly the same amount as the income tax or $\tau \cdot r \cdot K^{47}$

One way to deal with this problem is to adjust for the difference between the rate of capital growth based on new capital purchases (net of depreciation) and the risk-free rate. In the two-period example, in period $\mathrm{t}, \mathrm{I}_{\mathrm{t}}=\delta \mathrm{K}_{\mathrm{t}-1}$ and thus $\alpha=0$, and the additional deduction under the modified cash flow tax would be $(\mathrm{r}-\alpha) \mathrm{K}_{\mathrm{t}-1}=\mathrm{r} \mathrm{K}_{\mathrm{t}-1}=\mathrm{rK}^{48}$ Thus the adjusted cash flow tax would raise 0 , as it should. The difficulty here is in the measurement. Small changes in how either capital growth or the interest rate are measured can lead to very large adjustments once the figure is multiplied by the entire capital stock, indeed enough to swamp the other factors. I present one set of estimates below, but emphasize that it is highly sensitive to the assumptions used. If we are prepared to deal with a reduced sample, another way to deal with this problem is simply to focus on

\footnotetext{
${ }^{47}$ Under a hybrid income tax, where certain types of capital (e.g., intangible capital), $\mathrm{K}_{1}$, can be immediately expensed, while other types of capital, $\mathrm{K}_{2}$, still require capitalization, it is the growth rate of $\mathrm{K}_{2}$ that must match the interest rate for the GKS method to be accurate. The relevant correction if $\alpha_{2}$ does not equal r, is $\left(r-\alpha_{2}\right) K_{2, t}-1$.

${ }^{48}$ An equivalent method is suggested in Kalambokidis (1991) in which a corporation prior to the first period of analysis is given full expensing for a deemed "purchase" of all its capital, and at the end of the last period is taxed on a deemed sale of its capital. In the two-period example above, the cash flow tax will provide full deductions for the capital stock at the end of period $t-1$, at a cost to the Treasury of $\tau(1+r) \cdot K$ in terms of period t dollars, it will then collect $\tau \cdot \mathrm{r} \cdot \mathrm{K}$ on cash flows in period $\mathrm{t}$, and $\tau \mathrm{K}$ on the deemed sale of capital at the end of period t. In total, the adjusted cash flow tax now correctly raises $\$ 0$ in real terms.
} 
Figure 3: Portion of corporate tax lost switching to cash flow taxation, 1995-2013

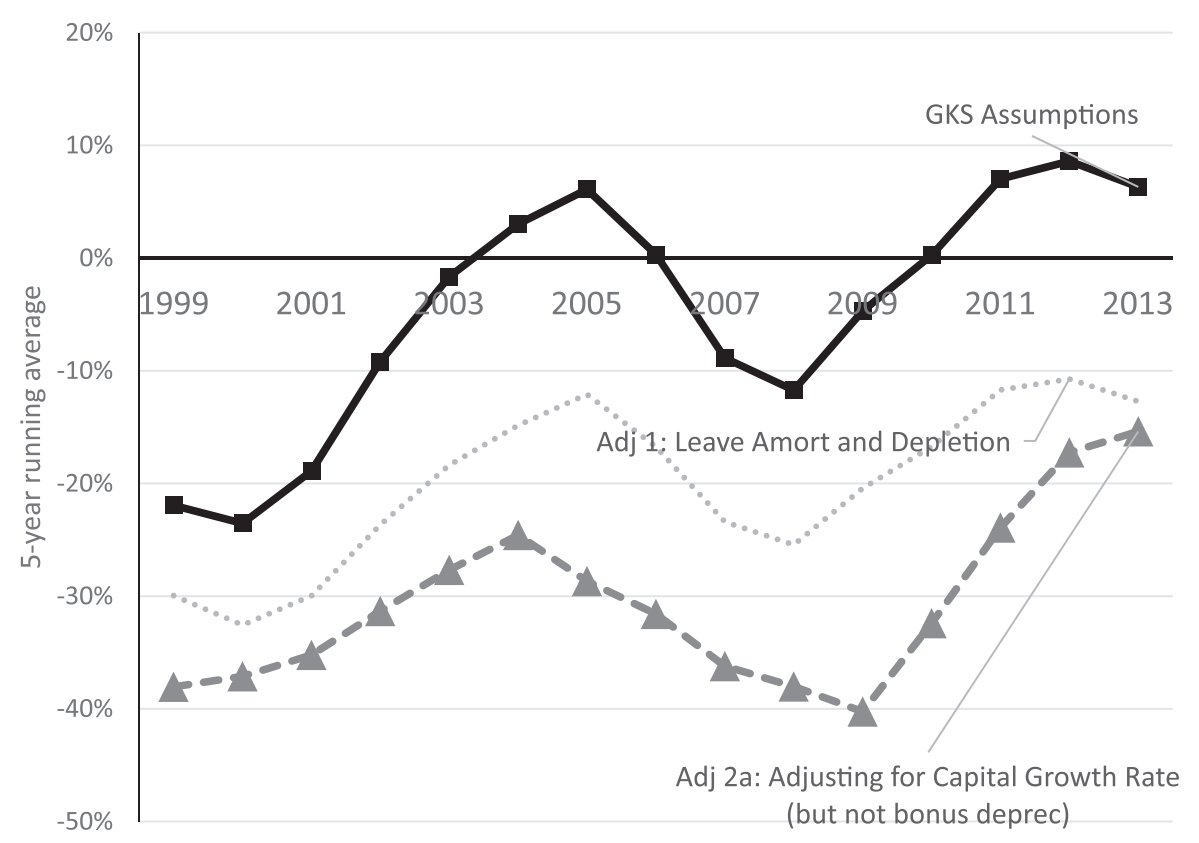

Notes: See main text and Appendix Table A-3 for more details on calculation.

years in which capital growth closely matches the risk-free interest rate (as I do in the analysis underlying Table 1).

Unlike the main results, Figure 3 accounts for the considerations just discussed in "Adjustment 2a" (the dashed line with triangular markers), which adjusts for differences between the rate of growth of physical capital (investment in structures, equipment, and inventories net of depreciation) compared to the risk-free rate proxied by the five-year constant maturity Treasury rate.

When measured using these assumptions, adjusting for differences between capital growth and the interest rate increases the portion of the tax estimated to have been raised from the normal return, particularly in the earlier part of the analysis. Again, I emphasize, however, that this pattern is partly dependent on which measures are chosen. Using a theoretically equivalent method or other shorter-term Treasury notes reverses the outcome, with the portion raised from the normal return falling after the adjustment. ${ }^{49}$

\footnotetext{
${ }^{49}$ Under the method outlined in note 48 , the portion of the tax raised from the normal return is reduced compared to the baseline in nearly all periods and is negative (i.e., the adjusted cash flow tax raises more revenue than the existing tax) for most of the 2000s. Likewise, if shorter maturity Treasury notes should be used to approximate the risk-free rate-since five-year notes will likely build in some inflation risk-adjusting for capital growth reduces the portion of the tax raised from the normal return from the baseline.
} 
An additional potential issue arises from firm heterogeneity, which I cannot observe in the aggregate tax return data. For revenue purposes this heterogeneity is mostly not relevant because it does not matter which firms pay what, so long as the total, aggregate figure is correct, ${ }^{50}$ but for analyzing the tax burden, firm heterogeneity missed by aggregate data is potentially important. The Treasury model relies on the aggregate composition of taxable corporate income being a decent proxy for what the average firm making an investment decision will face in terms of taxes on the normal return to that project and to supernormal returns from it. This in turn requires that (absolute levels of) investment and (absolute levels of) taxable income be tightly linked. ${ }^{51}$ Using data at the firm level on U.S. public companies, taxable income does in fact seem to be highly correlated with total investment. In 2013, for example, the correlation was 88 percent. ${ }^{52}$ This does not rule out all problems arising from firm heterogeneity, but suggests that it is not likely to be driving the aggregate figures too far off the result that would be reached if I could access firm level tax data.

\section{Explanation AND COMMENTARY}

In this section I briefly explain again the three important conclusions that can be drawn from my analysis: (1) under the Treasury's model, nearly the whole corporate tax burden fell on capital owners during the primary study period and they will receive the vast majority of the benefit from the rate cut in the 2017 Act; (2) the United States could permanently transition to an administratively simpler cash flow tax without sacrificing much revenue; (3) but this switch would have smaller efficiency benefits and spur less capital accumulation than is often thought. I then discuss whether risk premiums and imperfect loss offsets could drive the similarity of the cash flow tax and the actual tax during the primary study period. Although both risk and loss-offsets play a role, I argue that the primary explanation for the similarity of the two taxes comes from a low real normal return combined with the fact that the Tax Code allows the immediate deduction of many long-

\footnotetext{
${ }^{50}$ Firm-level data would still be useful for revenue purposes for analyzing in more detail the role of deficit firms (those facing losses).

${ }^{51}$ For example, a problem would arise if there were only two firms in the economy such that: (1) Company A does 75 percent of the investing, but earns only the normal return, contributing 10 percent of total taxable corporate income; and (2) Company B does only 25 percent of the investing, but earns very high supernormal returns and as a result contributes 90 percent of taxable income. In this case, we would conclude using aggregate data that the tax base is primarily supernormal returns, but that would not be indicative of the taxes applicable to the average investment decision.
}

\footnotetext{
${ }^{52}$ This analysis uses data from Compustat via WRDS. Taxable income is defined as pretax income (PI) as in Hanlon et al. (2019). Total investment is defined as physical investments (CAPX) plus intangible investment, which is defined as in Peters and Taylor (2017) to include R\&D and a portion of selling, general, and administrative expenses (SG\&A). The analysis excludes firms with no or blank investment in the data. A similar correlation (86 percent) holds for market value (including debt) and investment.
} 
lived expenses, like $\mathrm{R} \& \mathrm{D}$, employee training, advertising, and the like, which in turn make up an increasing share of investment.

\section{VII.A. Who Bears the Tax and Who Receives the Benefits from the Rate Cut?}

Although the debate about who bears the corporate tax is never ending, we are seemingly always arguing about a smaller and smaller tax as a share of the federal budget (and generally as a percent of GDP). When Harberger wrote in 1962, corporate tax receipts were 21 percent of federal revenue; prior to the 2017 Act's passage, they were about 11 percent of federal receipts and they are predicted to fall to 7 percent after accounting for the effect of the Act (Office of Management and Budget 2019). Yet in the two bills that have changed our federal tax system the most over the last 40 years, the 1986 Tax Reform Act and the 2017 Tax Act, changes to the corporate tax played a starring role.

Therefore, in trying to understand the effects of the 2017 Act-as with the 1986 reform-we must again return, like "boats against the current, borne ceaselessly back," to the question of who bears the tax and thus who will receive the benefits of the $\$ 1$ trillion rate cut over the next decade. Auerbach (2018) recently outlined again the reasons why we have had such a hard time arriving at a consensus on this question. First, there are a large number of potential margins of response to account for, and good estimates on many of them are hard to find. This is particularly true of the 2017 Act, which not only cut the statutory rate by 40 percent, but also transformed the international provisions of the corporate tax. Second, even if we had those estimates, they may be quickly rendered inaccurate by the evolution of the economy and changes in the international arena that are either exogenous or in response to cuts in the U.S. corporate rate (on tax competition, see Avi-Yonah 2000).

This article uses a relatively simple model that produces a simple conclusion: capital owners are likely to be the primary beneficiaries of the rate cut in the 2017 Act. The very early returns on the Act are consistent with this prediction, but obviously this conclusion is far from final. ${ }^{53}$ We also should not make too much of this: while firms might have shared some of the tax cut with workers through rent sharing, the main channel through which labor would benefit from the corporate rate cut in theory is capital deepening, which will lead to higher labor productivity and then higher wages. This process-if it occurs-will take time.

The move to expensing equipment also pushes the incidence even further toward capital owners under the Treasury model. Expensing under 168(k) makes the corporate tax today even more like a cash flow tax than bonus depreciation did during the primary study period, meaning that an even smaller percent of the corporate tax under the 2017 Act should fall on the normal return, and a larger percent on supernormal returns.

\footnotetext{
${ }^{53}$ Notwithstanding a few announcements of large bonuses being paid by firms, only 14 percent of firms in one survey said that they were using funds from the cut to raise base pay and 4 percent in another, larger, survey said that they had dedicated at least some funds from the rate cut to employee compensation (Fuhrmans 2018). Firms seem unlikely to be hesitant to report they have increased wages as a result of the Act, so this seems telling.
} 
In addition, the implications of my results for the 20 percent Qualified Business Income Deduction, under Section 199A, are similar to those of the corporate rate cut. My explanation for how little revenue the corporate tax raised from the normal return to capital largely applies to pass-through businesses as well. Just like C-corporations, pass throughs would have seen a low normal riskless rate of return, and nearly full cash flow treatment of intangible investments, along with accelerated depreciation for tangible investments. Indeed, because capital invested in pass throughs is likely to be less internationally mobile than that of C-corporations, there is stronger reason to suppose that taxes on pass throughs' supernormal returns in fact stick with capital owners. Thus, the benefit of the 20 percent deduction under Section 199A is likely to end up with capital owners. As with C-corporations, expensing under Section $168(\mathrm{k})$ will only push further in that direction.

\section{VII.B. Switching Fully to a Cash Flow Tax Would Come at Relatively Small Revenue Cost and Would Unlock Some Administrative Benefits}

The second main conclusion from the evidence is that we could move fully to a corporate cash flow tax at relatively low revenue cost. On balance, this would likely bring some administrative gains. Cash flow taxes are widely regarded as simpler because they do not require complex depreciation schedules and the concomitant accounting by corporations. As noted above, the Treasury estimates that businesses spend over 450 million hours tracking and calculating depreciation. ${ }^{54}$ Translated to a reasonable wage given the type of workers responsible for such tabulation, this probably implies a cost of at least $\$ 15$ billion per year. Eliminating those costs is economically important in its own right. The administrative case for an R-base cash flow tax is not so straightforward, however.

Complex as the current code is, it is a devil we know. Fully implementing an R-base tax would require Congress and the Treasury to face a new set of problems. Many common transactions, like leases, involve both a real and an implicit financial component and separating them would not be easy. ${ }^{55}$ Moreover, it can be quite difficult to tell "real" and "financial" transactions apart where the taxpayers find it advantageous to disguise one as the other. Trade credit, for example, can be embedded in the sale price, making it deductible under an R-base absent clear legislation or regulations. Likewise, a loan could be disguised as a sale of (actually worthless) intangible property combined with a set of royalty payments back to the purported seller (actually the lender). Moreover, the R-base provides no easy way of dealing with financial services firms, presumably requiring

\footnotetext{
${ }^{54}$ The costs of tabulating depreciation will be reduced, but far from eliminated, under Section $168(\mathrm{k})$ given that depreciation is retained for structures, equipment purchased prior to late 2017, and the like.

${ }^{55}$ Countries using value added taxes (VATs) face these problems as well and the treatment of leases appears to vary depending on the property in question (equipment, fixed residential property, fixed commercial property, or services/intangibles) and the lease terms (whether the lease is an "operating lease" in which the lessee returns the property to the lessor at the end of the term, or a "finance lease" in which the property will be sold at the end of the term with the proceeds largely going to the lessee).
} 
them to be identified and taxed under a different system. Still, there would likely be some administrative gains, though it is less clear how empirically important they are once the drawbacks of a R-base cash flow tax are also considered.

\section{VII.C. Switching Would Also Make the Real Economy More Efficient, But the Gains Would Be More Modest than Many Models Predict}

There is an important flip side of the argument made above. The fact that any administrative advantages of cash flow taxation can be unlocked at low revenue cost also by definition implies that the real efficiency gains from switching must be more modest than is often asserted. The similarity of the existing tax to a cash flow tax means that a full switch will likely produce less capital deepening than many models assume (e.g., Tax Foundation 2018). This does not mean these gains would be insignificant, though. Switching to a cash flow tax would eliminate some real excess burdens. First, different industrial sectors are taxed unevenly depending on the mix of assets they use in production. Indeed, sectors that use relatively little fixed capital (structures and equipment) and instead rely on human capital and intellectual property already likely find debt-financed investment subsidized by the Tax Code on the margin. ${ }^{56}$ Others, like mining and utilities, which use primarily physical capital, may still face an important tax on the normal return. These problems are substantially mitigated under the expensing provided in the 2017 Act, but would be fully eliminated under a full R-base cash flow tax. Moreover, a full R-base cash flow tax would eliminate the Tax Code's preference for debt over equity. This would lead to less leverage in the economy, which would make it more resilient to financial crises. In addition, switching fully to a cash flow tax would probably slightly increase the optimal corporate tax rate by more fully isolating supernormal returns, which in turn have a higher optimal tax rate (Fox \& Liscow 2019). Nevertheless, the key takeaway is that the switch to cash flow taxes would likely be less consequential for capital accumulation and productivity than many models predict.

\section{VII.D. What Explains the Similarity of the Existing Tax and the Cash Flow Tax?}

Risk

I have held off until this point discussing the breakdown of what the Treasury model defines as "supernormal" returns between the return to risk and economic rents. In a practical sense, it does not matter much to distributing the corporate tax under the Treasury model: taxes on both risk and economic rents are both assigned to capital

\footnotetext{
${ }^{56}$ These businesses receive essentially both the immediate expensing of long-lived assets and deductibility of interest. For projects earning the normal return, in order to recover the original investment subsidy provided by immediate expensing, the government must collect $\tau$ percent of future income from the project. By allowing for interest deductibility on top of immediate expensing, the government will collect less than $\tau$ percent of the earnings. We should note, however, that the government should recover something like the missing interest deduction by the inclusion of interest income by the lender, but not if the lender is tax exempt or is otherwise tax preferred like a pension fund.
} 
owners. ${ }^{57}$ Moreover, taxes on risk premia may raise money in expected value terms, but they likely impose relatively little burden (Gordon 1985). This is because taxes act like insurance by reducing the riskiness of investments. Through taxes, the investor gives up a portion of his risk premium and in return he faces less (after-tax) risk. Giving up part of the risk premium and facing lower risk is basically an even tradeoff for him. Thus these additional revenues "have positive expected value but have little market value to the investors who forgo them because of their risk" (Auerbach 2005).$^{58}$ Indeed, in simple models with perfect loss offsets, income and cash flow taxes impose no burden at all on the returns to risk because the investor can "undo" the tax by just increasing his investment in risky assets until his after-tax portfolio matches his pretax portfolio (Domar \& Musgrave 1944). ${ }^{59}$

There are at least two ways we might think about estimating how much of a role taxes on risk play in the corporate tax base. The first is to use a representative agent with average risk aversion and ask how much this agent would a value stream of revenue produced by the corporate tax? I calculate that the certainty equivalent value of corporate tax receipts from 1995-2013, assuming all the agents in the economy have the same, constant relative risk aversion coefficient of $3{ }^{60}$ On average, the corporate tax raised $\$ 185$ billion in 2013 dollars from nonfinancial C-corporations, with a standard deviation of \$39 billion. Risk-averse agents would value this income stream the same as a certain payment of $\$ 170$

\footnotetext{
${ }^{57}$ The assignment of the tax burden is to different capital owners, however. Taxes on rents are assumed to be borne by owners of corporate equities, while taxes on risk are assumed to be borne by all capital owners. Regardless, the distributional consequences of this distinction are small.

${ }^{58}$ To make this more concrete imagine a cash flow tax with $\tau=50$ percent. Assume an investor has a normal level of risk aversion and is indifferent between a safe return of 1 percent or a risky return with an expected return of 3 percent, where half the time the asset loses 1 percent and half the time it gains 7 percent and the investor has $\$ 100$. Assume also the investor uses the implicit investment subsidy of $\$ 100$ to invest more in the asset he purchased originally. If he chooses the safe asset, he will invest $\$ 200$ in the safe asset in Period 1 , he will receive $\$ 202$ in Period 2 and pay a tax of $\$ 101$, leaving him with a 1 percent return. Likewise, the government's portfolio is safe: it is going to obtain $\$ 101$ in Period 2 no matter what. If he invests $\$ 200$ in the risky asset, he has a 50 percent chance of receiving $\$ 214$ and a 50 percent chance of having $\$ 198$ in Period 2 before taxes. After taxes, the investor has a 50 percent chance of having $\$ 99$ and a 50 percent chance of having $\$ 107$, The government, likewise, has a 50 percent chance of collecting $\$ 99$ and a 50 percent chance of collecting $\$ 107$, or in expectation $\$ 103$. So the government will collect more money in expectation if the investor chooses the risky asset, but these extra revenues have no market value because they come with risks that exactly counterbalance their higher expected value.
}

\footnotetext{
${ }^{59}$ While investors facing such a tax can "undo" the effect of tax on the risk premium simply by increasing their investment in risky assets, under an income tax they cannot avoid a tax on the risk-free return of their entire portfolio. (see Warren 1996). One might reasonably wonder whether investors increasing the pretax riskiness of their portfolios makes the real economy more risky? The short answer is: maybe. As Kaplow (1994) shows, the government may change its own portfolio so that the there is no real effect from a new tax on risk. The question is largely orthogonal to the issue here, however, which is simply how much of the corporate tax base-given what investors have decided to do in light of the tax system-is the return to risk.
}

${ }^{60}$ The most accepted estimates of constant relative risk aversion coefficients are between 1 and 3 (Gandelman \& Hernández-Murillo 2015). Choosing a coefficient of less than 3 would result in an even smaller discount for the riskiness of corporate tax receipts. 
billion, only 8 percent less, suggesting risk is not driving much of the large overlap between the actual corporate tax base and the calculated hypothetical cash flow base.

By contrast, taxes on the returns to risk explain much more of the corporate tax base if we extrapolate from the market risk premium. Over time, the equity premium in the United States has been about 4.15 percent (e.g., Ayres \& Fox 2019). Under a cash flow tax, the government in essence becomes an equity partner and the tax base will have the same riskiness as the cash flows of the average (public) company. ${ }^{61}$ To get a rough sense of scale, consider how a tax on the risk premium would have compared to actual corporate tax revenues for nonfinancial C-corps over the primary study period. From 1995-2000, a 35 percent tax on the risk premium-assumed to be 4.15 percent of book value-would have averaged about 47 percent of actual corporate tax revenues. Since 2001, the same 35 percent tax on the risk premium would have averaged 65 percent of actual revenues (assuming the equity premium is time invariant).

These very different figures depending on which method we use to think about risk are partly a result of incomplete loss offsets, discussed below, which make the actual tax base less risky from the government's point of view than the hypothetical cash flow base with perfect loss offsets. More of the difference is driven by the fact that the historical equity premium in the United States cannot be explained by ordinary levels of risk aversion (Mehra \& Prescott 1985).

\section{Loss Offsets}

Incomplete loss offsets are another potential explanation for the similarity of the cash flow tax to the current tax. If the government does not fully refund tax losses, then even a cash flow tax can fall on the normal return. Therefore, my estimate of the revenue raised by the R-base cash flow tax may include some tax on the normal return that I do not account for above. Recall that under the cash flow tax the government is supposed to provide $\tau$ percent of the initial capital and collect $\tau$ percent of the income from the project. When firms with tax losses for a period invest in new projects, they do not receive $\tau$ percent of the initial capital from the government but, rather, additional loss offsets with a face value of $\tau$ percent. Economists at the Treasury have estimated that firms collect only about 50 percent of the face value of these loss offsets (Cooper \& Knittel 2010). As a sensitivity check, I therefore scale up actual loss offsets, which were used in a given year, by 100 percent. Doing so should roughly approximate the effect of having perfect loss offsets. I estimate that the R-base cash flow tax with perfect loss offsets would raise 10 percent less than my primary estimates that do not correct for imperfect loss offsets. This means that up to 10 percent of the existing tax may fall on the normal return but not be picked up as falling on the normal return under the GKS and Cronin et al. methods.

\footnotetext{
${ }^{61}$ Public companies still dominate the corporate tax base after weighting by size (Auerbach 2005).
} 


\section{Low Normal Rates of Return and Expensing of Long-Lived Assets}

In some ways the finding that we are currently raising relatively little tax from the normal rate of return is obvious. One can lose sight of the fact that the difference between a cash flow tax and an income tax is just a question of timing: When do you recover your basis? In a low interest rate and low inflation environment, the timing does not matter all that much (see Listokin 2016). For an asset with a seven-year life span, if inflation is 2 percent and the real interest rate is 2 percent, then even under straight-line depreciation, the difference between expensing and an income tax is 10 percent of the value of the asset. This is an important wedge, but much smaller than if inflation is 5 percent and real interest rates are 5 percent-there the wedge would be 25 percent of the value of the asset. Yet even during the 1990s when the real risk-free rate was 4 percent, only 20-30 percent of the tax was raised from the normal return. As noted in the introduction, a tax on the nominal normal rate of return on the book value of C-corps would have raised more than double what the actual tax raised from the normal return.

I believe a substantial factor explaining why the corporate tax raised a small percentage of its revenue from the normal return is the tax system's failure to keep up with the rise of intangible property. Corrado and Hulten (2010) estimate that intangible investment, broadly construed to include (1) software, (2) innovative property (scientific and nonscientific R\&D), and (3) brand investments and organizational investments (e.g., advertising, training of employees, strategic planning by executives), already by the 1990s formed a majority of business investment (see Figure 4). Yet the vast majority of these investments can be immediately expensed as self-developed intangibles. Having given cash flow treatment to more than 50 percent of investment, we should not be surprised that we collect relatively little from the normal return even when the normal return is high.

I begin to test the importance of changes in the risk-free rate of return, as measured by Treasury notes, and increases in the importance of intangible investment by extending my GKS-style comparison of the actual corporate tax and a hypothetical Rbase tax back to 1957. The collected data are presented in the Appendix in Table A-3. Confining my analysis to years in which the growth rate of physical capital is within 200 basis points of the risk-free rate as proxied by the five-year constant Treasury rate, I find that decreases in the risk-free rate and increases in intangible capital (as a percent of total capital) are associated with the corporate tax raising a smaller portion from the normal return (see Table 1).

These results are merely suggestive, but given the strength of the theoretical relationship between these variables and the portion of the corporate tax raised from the normal return, it is quite likely that both factors have played an important role in the decrease in the tax raised from the normal return over time. If these estimates were accurate, the increase in intangible assets from 15 percent of total fixed assets in 1957 to 37 percent in 2013 would be associated with a decline of about 10 percentage points in the portion of the tax raised from the normal return. Likewise, the decrease in the nominal risk-free rate from 6 percent in the mid-1990s to about 1.5 percent from 2009 to 2013 would have been 
Figure 4: Gross business fixed investment as a portion of nonfarm output.

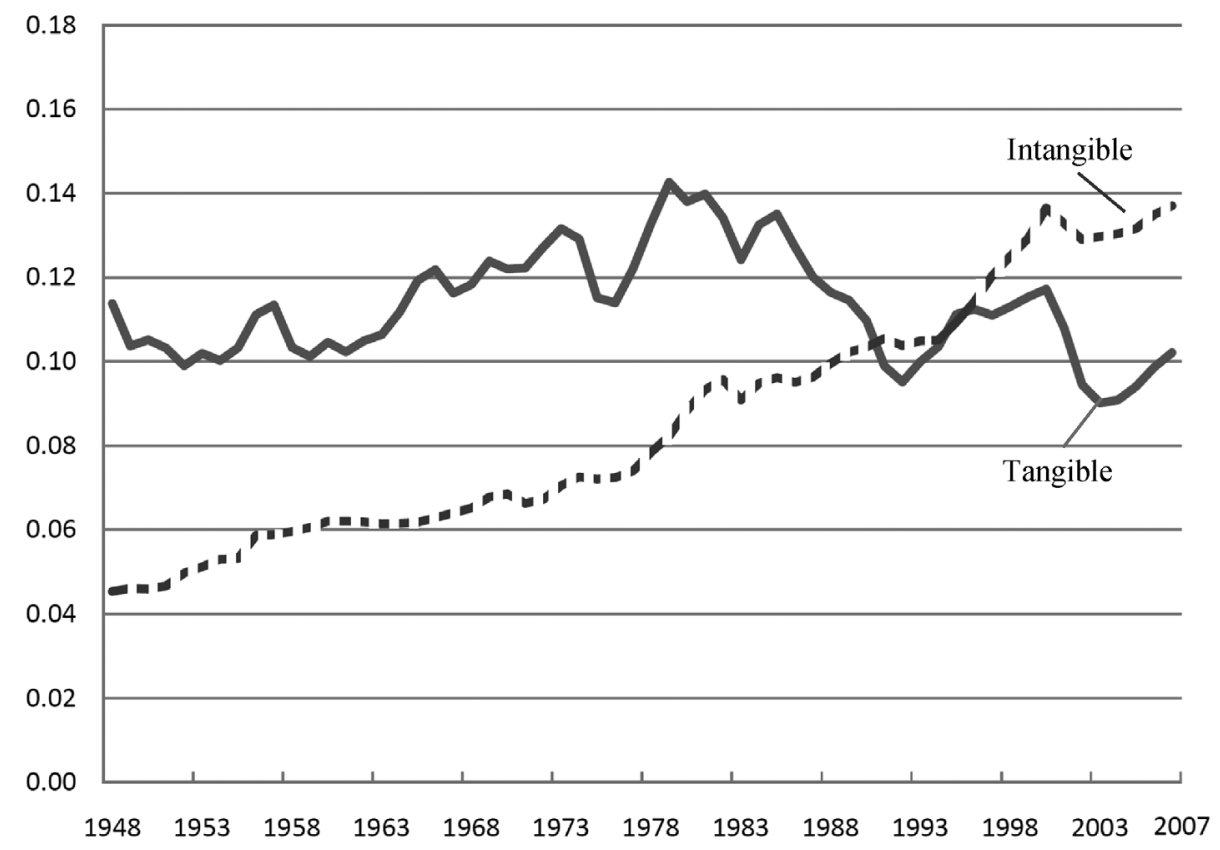

Note: Reproduced from Corrado and Hulten (2010).

Table 1: Association Between Portion of the Corporate Tax Raised from Normal Return and Risk-Free Rate, Intangible Capital

Estimated \% of Tax Raised from Normal Return

Intangible assets as a percent of total capital

$$
\begin{aligned}
& -0.5221 \\
& (0.2526)^{*} \\
& 1.6786 \\
& (0.7090)^{* *} \\
& 0.33 \\
& 24
\end{aligned}
$$

$R^{2}$

$* p<0.1 ; * *<0.05$.

associated with a decline of about 7.5 percentage points in the portion of the tax raised from the normal return.

\section{Conclusion}

I present new empirical evidence from U.S. corporate tax returns showing that the corporate tax raised very little revenue from the normal return to capital from 1995 to 2013. 
This means that under the Treasury's model, the full corporate tax burden should be assigned to capital owners. In turn this suggests that capital owners will reap the vast majority of the benefit from the $\$ 1$ trillion rate cut in the 2017 Act over the next decade. The results also imply that it would be less costly than commonly thought to move permanently to a simpler and modestly more efficient cash flow tax on corporations.

\section{REFERENCES}

Alder, Simeon, David Lagakos, \& Lee Ohanian (2017) "Labor Market Conflict and the Decline of the Rust Belt," Working Paper. Available at https://economics.ucr.edu/wp-content/uploads/2019/10/Ohanian-paper-for-4-13-18-seminar-1.pdf.

Auerbach, Alan J. (1983) "Taxation, Corporate Financial Policy and the Cost of Capital," 21(3) J. of Economic Literature 905.

(2005) "Who Bears the Corporate Tax? A Review of What We Know," 20 Tax Policy \& the Economy 1.

(2010) A Modern Corporate Tax. Washington, DC: Center for American Progress \& the Hamilton Project.

(2018) "Measuring the Effects of Corporate Tax Cuts," 32(4) J. of Economic Perspectives 97.

Avi-Yonah, Reuven S. (2000) "Globalization, Tax Competition, and the Fiscal Crisis of the Welfare State," 113(7) Harvard Law Rev. 1573.

Ayres, Ian, \& Edward Fox (2019) "Alpha Duties: The Search for Excess Returns and Appropriate Fiduciary Duties," 97 Texas Law Rev. 445.

Brown, E. Cary (1948) "Business-Income Taxation and Investment Incentives," in Income, Employment and Public Policy: Essays in Honor of Alvin E. Hansen. New York: WW Norton \& c.

Clausing, Kimberly A. (2013) "Who Pays the Corporate Tax in a Global Economy?" 66(1) National Tax J. 151.

Congressional Budget Office (CBO) (2018) The Budget and Economic Outlook: 2018 to 2028. Washington, DC: Congressional Budget Office.

Cooper, Michael G., \& Matthew J. Knittel (2010) "The Implications of Tax Asymmetry for US Corporations," 63(1) National Tax J. 33.

Corrado, Carol A., \& Charles R. Hulten (2010) "How Do You Measure a 'Technological Revolution'?" 100(2) American Economic Rev. 99.

Cronin, Julie Anne, Emily Y. Lin, Laura Power, \& Michael Cooper (2013) "Distributing the Corporate Income Tax: Revised US Treasury Methodology," 66(1) National Tax J. 239.

Cunningham, Noël B., \& Mitchell L. Engler (2012) "Prescription for Corporate Income Tax Reform: A Corporate Consumption Tax," 66 Tax Law Rev. 445.

Davidson, Carl, \& Lawrence W. Martin (1985) "General Equilibrium Tax Incidence Under Imperfect Competition: A Quantity-Setting Supergame Analysis,” 93(6) J. of Political Economy 1212.

Desai, Mihir A., C. Fritz Foley, \& James R. Hines, Jr. (2007) "Labor and Capital Shares of the Corporate Tax Burden: International Evidence," Working Paper. Available at https://www.aeaweb. org/conference/2011/retrieve.php?pdfid=326.

Devereux, Michael P., \& Rachel Griffith (2003) "Evaluating Tax Policy for Location Decisions," 10(2) International Tax \& Public Finance 107.

Dharmapala, Dhammika (2014) "What Do We Know About Base Erosion and Profit Shifting? A Review of the Empirical Literature," 35(4) Fiscal Studies 421.

Domar, Evsey D., \& Richard A. Musgrave (1944) "Proportional Income Taxation and Risk-Taking," 58(3) Q.J. of Economics 388.

Fane, George (1984) "The Incidence of a Tax on Pure Rent: The Old Reason for the Old Answer," 92(2) J. of Political Economy 329. 
Feldstein, Martin (1977) "The Surprising Incidence of a Tax on Pure Rent: A New Answer to an Old Question," 85(2) J. of Political Economy 349.

Fox, Edward, \& Zachary Liscow (2019) "The Uneasy Case for Higher Corporate Taxes," Working Paper.

Fuhrmans, Vanessa (2018) "Business News: Tax Cuts Have Limited Effect on Pay," October 3 Wall Street J.

Gandelman, Néstor, \& Rubén Hernández-Murillo (2015) "Risk Aversion at the Country Level," 97(1) Federal Reserve Bank of St. Louis Rev. 53.

Gentry, William M., \& R. Glenn Hubbard (1997) "Distributional Implications of Introducing a Broad-Based Consumption Tax" 11 Tax Policy E the Economy 1.

Gordon, Roger H. (1985) "Taxation of Corporate Capital Income: Tax Revenues Versus Tax Distortions," 100(1) Q.J. of Economics 1.

Gordon, Roger H., \& James R. Hines, Jr. (2002) "International Taxation," 4 Handbook of Public Economics 1935 .

Gordon, Roger H., Laura Kalambokidis, J. Rohaly, \& Joel Slemrod (2004a) "Toward a Consumption Tax, and Beyond," 94(2) American Economic Rev. 161.

Gordon, Roger H., Laura Kalambokidis, \& Joel Slemrod (2004b) "Do We Now Collect Any Revenue from Taxing Capital Income?" 88(1) J. of Public Economics 981.

Gordon, Roger H., \& Joel Slemrod (1988) "Do We Collect Any Revenue from Taxing Capital Income?" 2 Tax Policy Eं the Economy 89.

Gravelle, Jennifer (2013) "Corporate Tax Incidence: Review of General Equilibrium Estimates and Analysis,” 66(1) National Tax J. 185.

Hanlon, Michelle, Jeffrey L. Hoopes, \& Joel Slemrod (2019) “Tax Reform Made Me Do It!” 33 (1) Tax Policy E the Economy 33.

Harberger, Arnold C. (1962) "The Incidence of the Corporation Income Tax," 70(3) J. of Political Economy 215.

Hines, James R., Jr., R. Griffith \& P. B. Sørensen (2010) "International Capital Taxation," in S. Adam, T. Besley, R. Blundell, S. Bond, R. Chote, M.Gammie, P. Johnson, G. Myles \& J. Poterba, eds., Dimensions of Tax Design: The Mirlees Review, pp. 914-96. Oxford: Oxford Univ. Press.

Kahng, Lily (2014) "The Taxation of Intellectual Capital," 66 Florida Law Rev. 2229.

Kalambokidis, Laura (1991) "What Is Being Taxed? A Test for the Existence of Excess Profit in the Corporate Income Tax Base," unpublished dissertation.

Kaplow, Louis (1994) "Taxation and Risk Taking: A General Equilibrium Perspective," 47(4) National Tax J. 789.

Krishnamurthy, Arvind, \& Annette Vissing-Jorgensen (2012) "The Aggregate Demand for Treasury Debt," 120(2) J. of Political Economy 233.

Listokin, Yair (2016) "How to Think About and Teach Income Tax When Interest Rates Are Zero," 115(1) Tax Notes 1.

Liu, Li, \& Rosanne Altshuler (2013) "Measuring the Burden of the Corporate Income Tax Under Imperfect Competition," 66(1) National Tax J. 215.

Margalioth, Yoram (2007) "Not a Panacea for Economic Growth: The Case of Accelerated Depreciation," 26 Virginia Tax Rev. 493.

Mehra, Rajnish, \& Edward C. Prescott (1985) "The Equity Premium: A Puzzle," 15(2) J. of Monetary Economics 145.

Office of Management and Budget (OMB) (2019) Historical Tables, Table 2.1. Available at https:// www.whitehouse.gov/omb/historical-tables/.

Peters, Ryan H., \& Lucian A. Taylor (2017) "Intangible Capital and the Investment-Q Relation," 123 (2) J. of Financial Economics 251.

Power, Laura, \& Austin Frerick (2016) "Have Excess Returns to Corporations Been Increasing Over Time?" 69(4) National Tax J. 831.

Rubin, Richard (2017) “Treasury Removes Paper at Odds with Mnuchin's Take on Corporate-Tax Cut's Winners," September 28 Wall Street J. 
Schularick, Moritz, \& Alan M. Taylor (2012) "Credit Booms Gone Bust: Monetary Policy, Leverage Cycles, and Financial Crises, 1870-2008," 102(2) American Economic Rev. 1029.

Slemrod, Joel (2007) "Does the United States Tax Capital Income?" in H. Aaron, L. Burman, \& C. Steuerle, eds., Taxing Capital Income. Washington DC: The Urban Institute Press.

Suárez Serrato, Juan Carlos (2018) "Unintended Consequences of Eliminating Tax Havens," NBER Working Paper No. 24850. Available at https://www.nber.org/papers/w24850.

Suárez Serrato, Juan Carlos, \& Owen Zidar (2016) "Who Benefits from State Corporate Tax Cuts? A Local Labor Markets Approach with Heterogeneous Firms," 106(9) American Economic Rev. 2582.

Treasury Department (2011) Supporting Statement [to OIRA Under Paper Work Reduction Act]. Available at https://www.reginfo.gov/public/do/DownloadDocument?objectID=44105901.

(2013) Fiscal Year 2013 Tax Expenditures. Available at https://www.treasury.gov/resourcecenter/tax-policy/Documents/Tax-Expenditures-FY2013.pdf.

Warren, Alvin C. Jr. (1996) "How Much Capital Income Taxed Under an Income Tax Is Exempt Under a Cash Flow Tax" 52 Tax Law Rev. 1.

Weisbach, David A. (2004) "The (Non) Taxation of Risk," 58 Tax Law Rev. 1. 


\section{A. APPENDIX: ADDITIONAL TABLES AND FIGURES}

Table A-1: Comparing a 35 Percent Tax on Normal Rate of Return to Actual Corporate Tax Revenue for Nonfinancial C-Corporations (Billions of Year-2013 Dollars)

\begin{tabular}{|c|c|c|c|c|c|c|c|c|}
\hline \multirow[b]{2}{*}{ Year } & \multirow[b]{2}{*}{$\begin{array}{l}\text { Annual Tax } \\
\text { Revenue from } C \text { - } \\
\text { Corps }\end{array}$} & \multirow[b]{2}{*}{$\begin{array}{l}\text { Net-Worth } \\
\text { of C-Corps }\end{array}$} & \multicolumn{2}{|c|}{ Avg. Risk-Free Rate } & \multicolumn{2}{|c|}{$\begin{array}{l}\text { Avg. Annual Revenue } \\
\text { Raised from } 35 \% \text { Tax } \\
\text { on Normal Return }\end{array}$} & \multicolumn{2}{|c|}{$\begin{array}{c}\text { As a } \% \text { of Actual } \\
\text { Revenue }\end{array}$} \\
\hline & & & Nominal & Real & $\begin{array}{l}\text { Nominal } \\
\text { Risk- } \\
\text { Free Rate }\end{array}$ & $\begin{array}{l}\text { Real } \\
\text { Risk- } \\
\text { Free Rate }\end{array}$ & $\begin{array}{c}\text { Nominal } \\
\text { Risk- } \\
\text { Free Rate }\end{array}$ & $\begin{array}{c}\text { Real } \\
\text { Risk- } \\
\text { Free Rate }\end{array}$ \\
\hline & & & & & (6) & (7) & (8) & (9) \\
\hline (1) & (2) & (3) & (4) & (5) & $=(3) \cdot(4)$ & $=(3) \cdot(5)$ & $=(6) /(2)$ & $=(7) /(2)$ \\
\hline \multicolumn{9}{|l|}{ Average } \\
\hline 1994 to 2003 & 164.48 & 6,538 & $5.70 \%$ & $3.33 \%$ & 130.54 & 76.23 & $79 \%$ & $46 \%$ \\
\hline 2004 to 2013 & 206.52 & 8,110 & 3.51 & 1.13 & 99.54 & 31.96 & $48 \%$ & $15 \%$ \\
\hline 1994 & 157.80 & 4,601 & $7.09 \%$ & 4.41 & 114.09 & 71.02 & $72 \%$ & $45 \%$ \\
\hline 1995 & 167.41 & 4,877 & 6.57 & 4.04 & 112.22 & 68.89 & $67 \%$ & $41 \%$ \\
\hline 1996 & 176.73 & 5,313 & 6.44 & 3.12 & 119.82 & 58.04 & $68 \%$ & $33 \%$ \\
\hline 1997 & 186.68 & 5,613 & 6.35 & 4.65 & 124.83 & 91.39 & $67 \%$ & $49 \%$ \\
\hline 1998 & 180.19 & 6,166 & 5.26 & 3.65 & 113.58 & 78.80 & $63 \%$ & $44 \%$ \\
\hline 1999 & 193.04 & 6,887 & 5.65 & 2.96 & 136.09 & 71.38 & $70 \%$ & $37 \%$ \\
\hline 2000 & 191.65 & 8,149 & 6.03 & 2.64 & 171.98 & 75.39 & $90 \%$ & $39 \%$ \\
\hline 2001 & 141.48 & 8,045 & 5.02 & 3.47 & 141.37 & 97.68 & $100 \%$ & $69 \%$ \\
\hline 2002 & 116.67 & 7,799 & 4.61 & 2.24 & 125.92 & 61.04 & $108 \%$ & $52 \%$ \\
\hline 2003 & 133.12 & 7,932 & 4.01 & 2.13 & 111.43 & 59.25 & $84 \%$ & $45 \%$ \\
\hline 2004 & 173.86 & 7,996 & 4.27 & 1.02 & 119.54 & 28.42 & $69 \%$ & $16 \%$ \\
\hline 2005 & 250.27 & 8,771 & 4.29 & 0.87 & 131.66 & 26.81 & $53 \%$ & $11 \%$ \\
\hline 2006 & 276.32 & 8,393 & 4.80 & 2.25 & 140.86 & 66.22 & $51 \%$ & $24 \%$ \\
\hline 2007 & 255.80 & 8,253 & 4.63 & 0.55 & 133.88 & 15.98 & $52 \%$ & $6 \%$ \\
\hline 2008 & 190.37 & 7,266 & 3.66 & 3.57 & 93.19 & 90.86 & $49 \%$ & $48 \%$ \\
\hline 2009 & 166.11 & 7,443 & 3.26 & 0.54 & 85.03 & 14.14 & $51 \%$ & $9 \%$ \\
\hline 2010 & 174.28 & 8,107 & 3.22 & 1.72 & 91.23 & 48.79 & $52 \%$ & $28 \%$ \\
\hline 2011 & 167.12 & 7,992 & 2.78 & -0.18 & 77.81 & -5.05 & $47 \%$ & $-3 \%$ \\
\hline 2012 & 198.30 & 8,184 & 1.80 & 0.06 & 51.66 & 1.79 & $26 \%$ & $1 \%$ \\
\hline 2013 & 212.74 & 8,690 & 2.35 & 0.85 & 71.48 & 25.80 & $34 \%$ & $12 \%$ \\
\hline
\end{tabular}

Notes: Tax revenue and net worth of C-corporations obtained from Table 12 of the IRS Statistics of Income (SOI) Complete Corporations Report. Nominal risk-free rate is the average of the 10-year T-bill rate over the course of each year, obtained from the St. Louis Federal Reserve Bank (FRED). The real risk-free rate is obtained by removing the Consumer Price Index measure of inflation for that year. Nonfinancial industry defined prior to 1998 as all industries except SIC Codes 60-67. After 1998, nonfinancial industries are defined to be as close to equivalent to the pre-1998 definition as possible. This means all industries except NAICS Codes 52-53 and 55. However, we count NAICS 532 (rental and leasing services) as nonfinancial because it was nonfinancial under the SIC definitions. 
Table A-2: Corporate Returns Attributable to the Normal Return to Capital Using Gentry and Hubbard (1997) Method

\begin{tabular}{|c|c|c|c|c|}
\hline \multicolumn{2}{|l|}{ Period } & \multicolumn{2}{|c|}{ Annual Nominal Return } & \multirow{2}{*}{$\frac{\text { Corporate Return }}{\text { Attributable to Normal Return }}$} \\
\hline Start & End & Stocks $^{1}$ & Risk-Free Rate $^{2}$ & \\
\hline 1980 & 1989 & $23.47 \%$ & $10.58 \%$ & $45 \%$ \\
\hline 1995 & 2013 & $13.14 \%$ & $4.47 \%$ & $34 \%$ \\
\hline 1995 & 2002 & $14.16 \%$ & $5.74 \%$ & $41 \%$ \\
\hline 2003 & 2013 & $12.41 \%$ & $3.55 \%$ & $29 \%$ \\
\hline 1965 & 2015 & $13.09 \%$ & $6.51 \%$ & $50 \%$ \\
\hline
\end{tabular}

${ }^{1}$ Using the Center for Research in Security Prices total return index, which is the return on a market-cap-weighted average of all stocks trading on the NYSE, NASDAQ, and AMEX, including dividends. The return is then grossed up by 25 percent to account for corporate taxes paid as in Gentry and Hubbard (1997).

${ }^{2}$ Defined as the 10-year T-bill rate. For each year, the risk-free return is based on the average over the year.

Notes: Although Gentry and Hubbard's technique provides a convenient way to approximate the portion of corporate income accounted for by the normal return to capital, I prefer not to interpret it as the percent of corporate taxes raised from the normal return. This is because it does not account for how the corporate tax differs from a pure income tax with full capitalization of all long-lived assets and no accelerated depreciation. It is also quite sensitive to stock market booms and busts. 


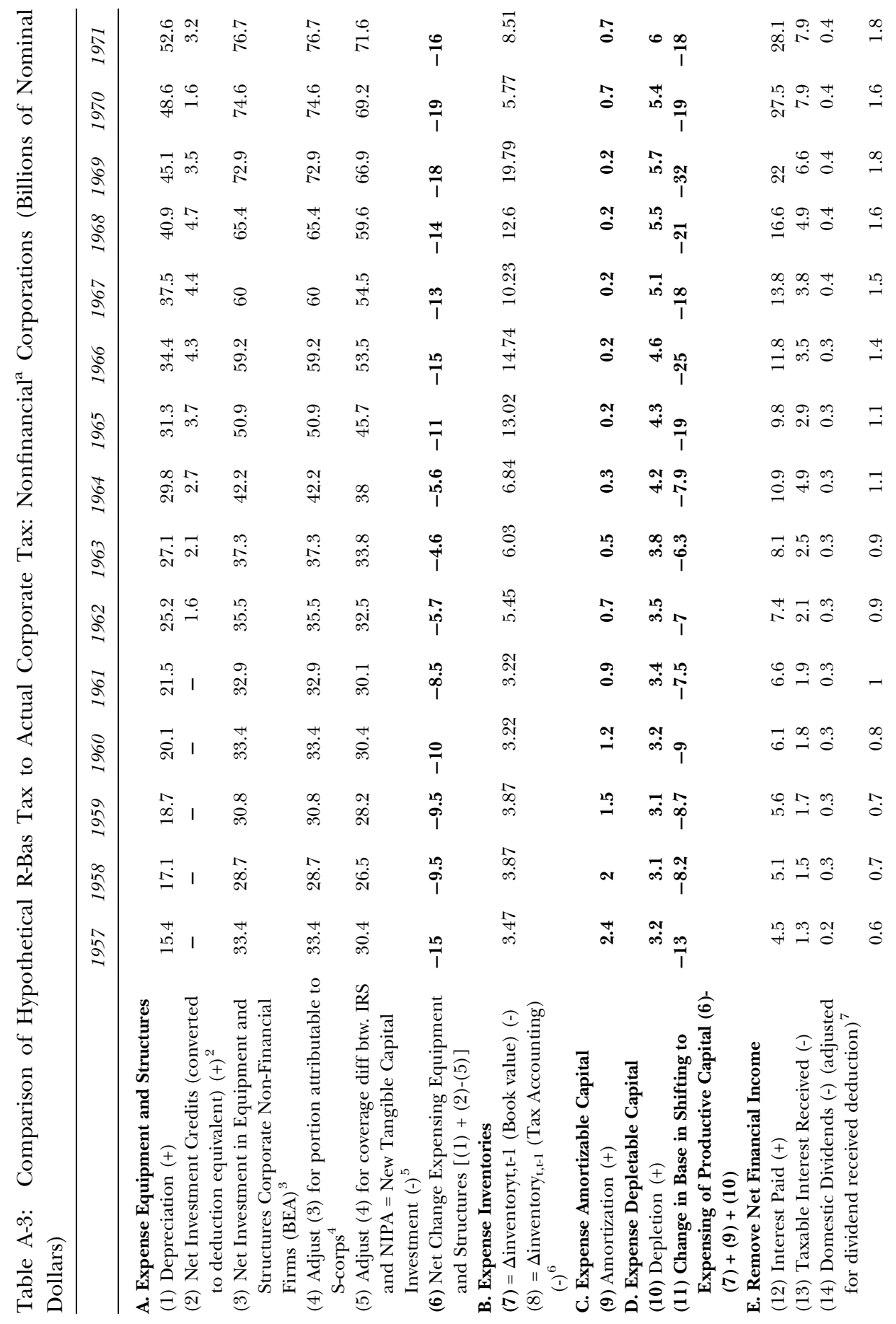




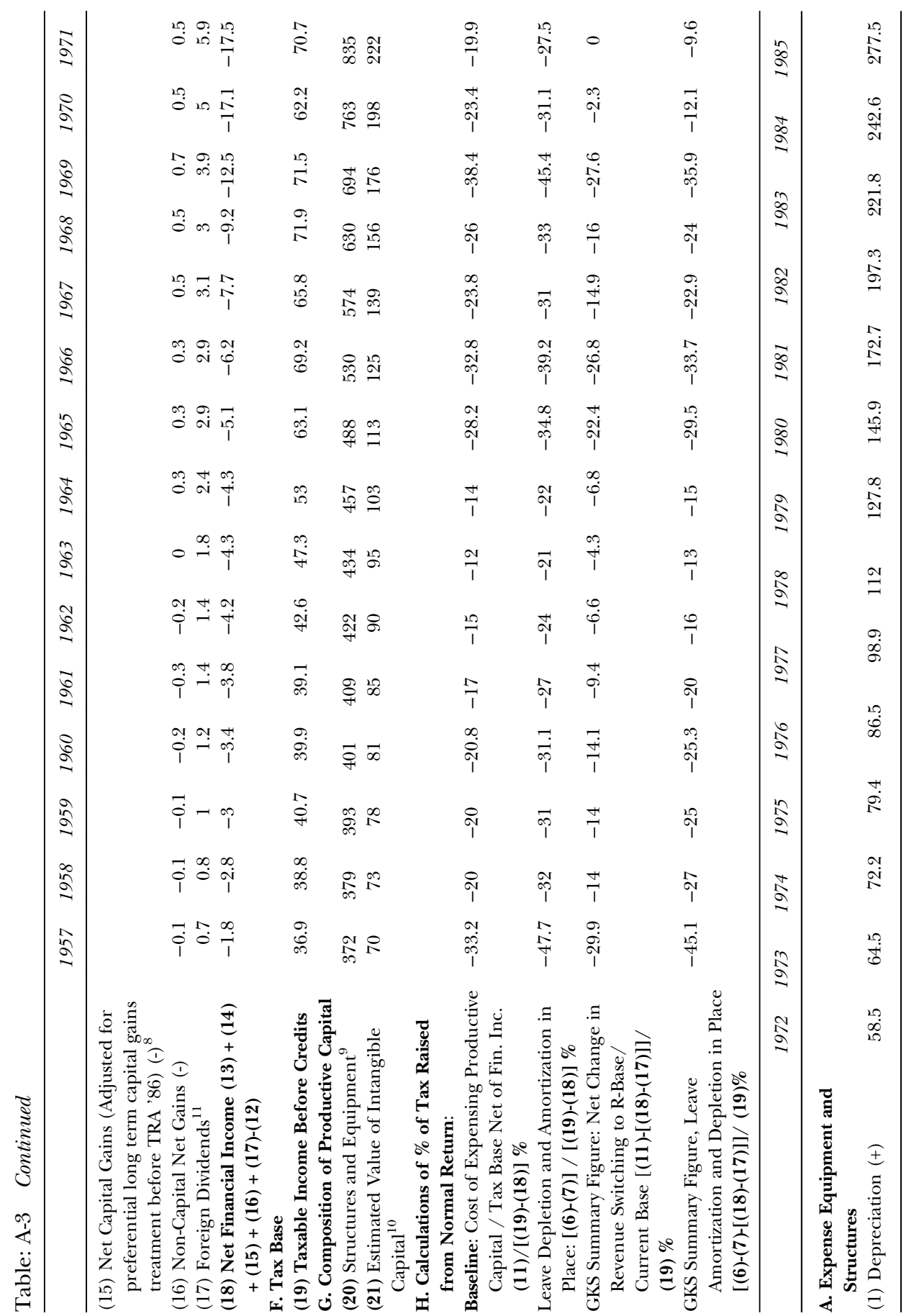




\begin{tabular}{|c|c|c|c|c|c|c|c|c|c|}
\hline $\begin{array}{l}n \\
\hat{\sigma}\end{array}$ & $\stackrel{\vec{\rho}}{\circ}$ & $\begin{array}{l}n \\
\text { an } \\
\text { m. }\end{array}$ & 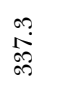 & $\begin{array}{l}\text { y. } \\
\stackrel{2}{m}\end{array}$ & $\underset{\Upsilon}{\Upsilon}$ & $\begin{array}{l}\text { के } \\
\text { g. }\end{array}$ & 70 & 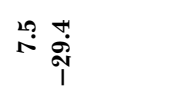 & \\
\hline$\stackrel{+}{2}$ & $\begin{array}{l}10 \\
10 \\
00\end{array}$ & $\stackrel{\vec{\infty}}{a}$ & $\begin{array}{l}\vec{c} \\
\frac{\infty}{\infty}\end{array}$ & $\begin{array}{l}\text { वे } \\
\text { वे }\end{array}$ & 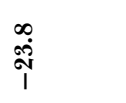 & $\begin{array}{l}\text { भి } \\
\text { ஸु }\end{array}$ & $\stackrel{m}{+}$ & $\stackrel{\infty}{\stackrel{\infty}{r}}$ & \\
\hline$\stackrel{m}{\alpha}$ & $\begin{array}{l}\infty \\
\dot{N} \\
\infty\end{array}$ & $\frac{r}{\stackrel{N}{N}}$ & 点 & 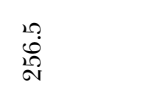 & $\stackrel{9}{i}$ & $\begin{array}{l}0 \\
\sim 1 \\
\infty \\
\infty\end{array}$ & की & $\stackrel{+}{\sim} \stackrel{\infty}{i}$ & \\
\hline ڤ్ & $\overrightarrow{0}$ & 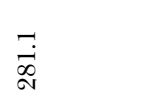 & $\underset{\sim}{\breve{\infty}}$ & $\begin{array}{l}10 \\
10 \\
\text { o }\end{array}$ & هิ่ & $\begin{array}{l}\hat{N} \\
\hat{i} \\
1\end{array}$ & $m_{\infty}^{\infty}$ & $\stackrel{\infty}{\infty} \underset{0}{0}$ & \\
\hline$\approx$ & $\underset{\dot{g}}{\ddot{g}}$ & $\begin{array}{l}\infty \\
\text { â } \\
\text { Nats }\end{array}$ & $\begin{array}{l}\infty \\
\text { a } \\
\text { Na }\end{array}$ & ণ & $\begin{array}{l}a \\
\infty \\
0 \\
1\end{array}$ & \begin{tabular}{l} 
Yै \\
के \\
\multirow{+}{*}{}
\end{tabular} & $\overrightarrow{+}$ & ‥ & \\
\hline$\approx$ & $\stackrel{\vec{m}}{\dot{m}}$ & $\begin{array}{l}20 \\
\stackrel{2}{9} \\
\text { a }\end{array}$ & $\begin{array}{l}\stackrel{10}{S} \\
\stackrel{S}{N}\end{array}$ & $\begin{array}{l}\text { ข } \\
\text { ஸे } \\
\text { ปे }\end{array}$ & $\begin{array}{l}10 \\
\infty \\
10 \\
1\end{array}$ & $\begin{array}{l}\vec{b} \\
\dot{\vec{V}}\end{array}$ & ฯ̣ & 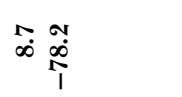 & \\
\hline$\stackrel{\Omega}{ล}$ & में & 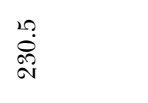 & $\begin{array}{l}10 \\
\text { ôे } \\
\text { जे }\end{array}$ & $\frac{\sigma}{\sigma}$ & 今. & $\bar{g}$ & ๆ̛ & $\stackrel{\mathfrak{N}}{\stackrel{\mathfrak{I}}{J}}$ & \\
\hline$\stackrel{\infty}{2}$ & $\begin{array}{l}0 \\
109 \\
09\end{array}$ & $\begin{array}{l}\stackrel{3}{\circ} \\
\stackrel{8}{\varrho}\end{array}$ & $\begin{array}{l}\infty \\
\stackrel{2}{2} \\
\mathscr{2}\end{array}$ & $\begin{array}{l}\ddot{4} \\
\stackrel{\infty}{\infty}\end{array}$ & & $\begin{array}{l}\text { Oे } \\
\text { 10 } \\
\text { f }\end{array}$ & - & 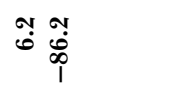 & \\
\hline 会 & $\begin{array}{l}\text { ṽ } \\
\text { Ñ }\end{array}$ & 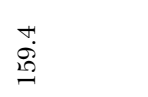 & $\begin{array}{l}\forall \\
\stackrel{7}{0} \\
\stackrel{10}{2}\end{array}$ & $\begin{array}{l}\text { ơ } \\
\text { ปี } \\
\text { Iี }\end{array}$ & $\bar{p}$ & $\begin{array}{l}\hat{\sigma} \\
\text { ò } \\
\text { of }\end{array}$ & $\stackrel{\infty}{0}$ & $\begin{array}{lc}0 & 0 \\
20 & 0 \\
0 & 0 \\
1\end{array}$ & \\
\hline م̊ & 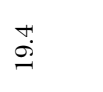 & $\begin{array}{l}20 \\
\stackrel{1}{2} \\
\text { ov }\end{array}$ & 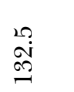 & $\stackrel{\mathscr{V}}{\sim}$ & ণิึ่ & \begin{tabular}{l}
$\infty$ \\
$\infty$ \\
\multirow{n}{*}{} \\
$\infty$
\end{tabular} & $\stackrel{\infty}{0}$ & مَ & \\
\hline ha & さ̃ & $\begin{array}{l}\text { ฯ } \\
\stackrel{\Xi}{\Xi}\end{array}$ & $\stackrel{o ̛ ̣}{\varrho}$ & $\stackrel{\vec{g}}{=}$ & ฟิ & $\begin{array}{l}\infty \\
\infty \\
10\end{array}$ & $\stackrel{0}{0}$ & ๓ి & \\
\hline 荅 & $\underset{\infty}{+}$ & $\begin{array}{l}\stackrel{\infty}{\stackrel{\infty}{\Xi}} \\
=\end{array}$ & $\begin{array}{l}\infty \\
\stackrel{\infty}{\Xi}\end{array}$ & 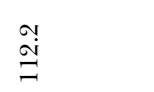 & $\stackrel{0}{\infty}$ & $\begin{array}{l}\infty \\
\infty \\
\infty \\
\infty\end{array}$ & $\ddot{\theta}$ & $\begin{array}{ll}\infty & 0 \\
\infty & 0 \\
- & 0 \\
- & 1\end{array}$ & \\
\hline$\stackrel{n}{\alpha}$ & $\stackrel{0}{1}$ & 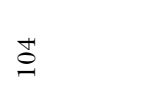 & $\stackrel{+}{\circ}$ & $\begin{array}{l}\infty \\
\infty \\
\infty\end{array}$ & ث্ণি & 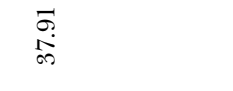 & $\stackrel{\infty}{0}$ & ণ̣ & \\
\hline$\stackrel{N}{N}$ & 7 & $\underset{\infty}{\stackrel{0}{\infty}}$ & $\underset{\infty}{\stackrel{0}{\infty}}$ & . & $\stackrel{\infty}{\stackrel{\infty}{1}}$ & $\begin{array}{l}\Delta \\
\Delta \\
a \\
a\end{array}$ & $\stackrel{g}{0}$ & ڤே & \\
\hline & 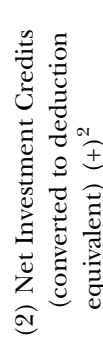 & 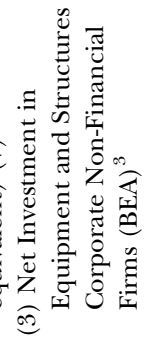 & 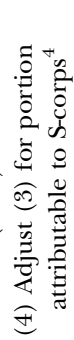 & 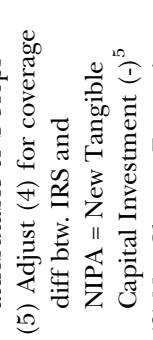 & 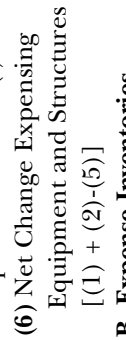 & 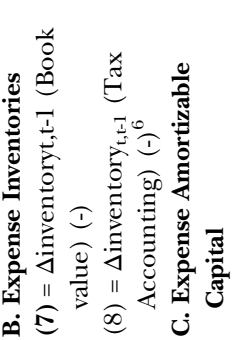 & 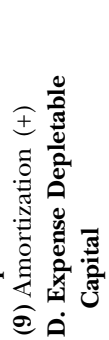 & 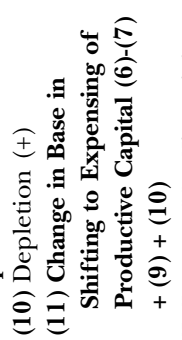 & 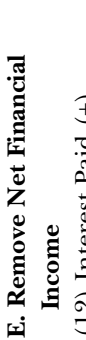 \\
\hline
\end{tabular}




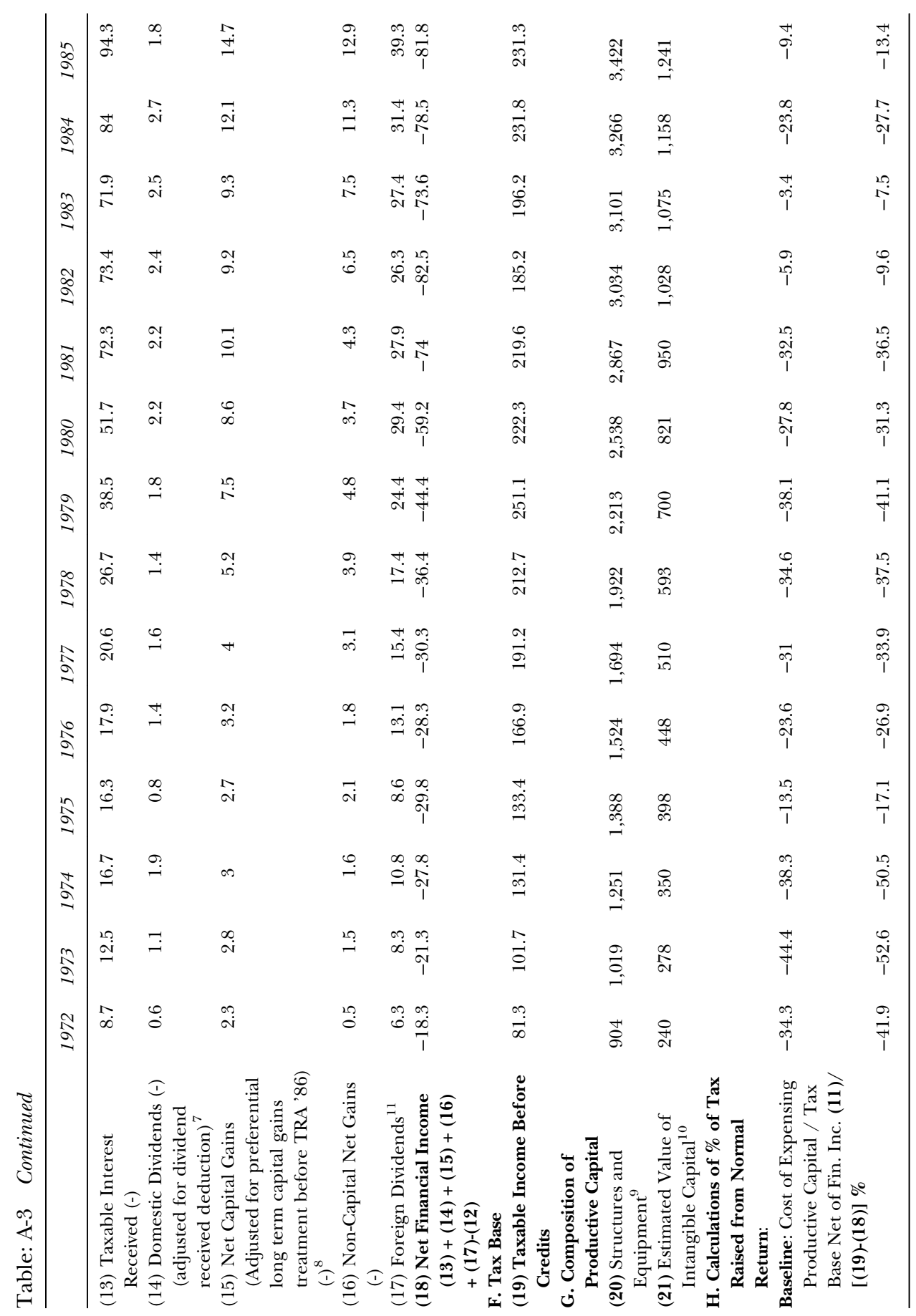




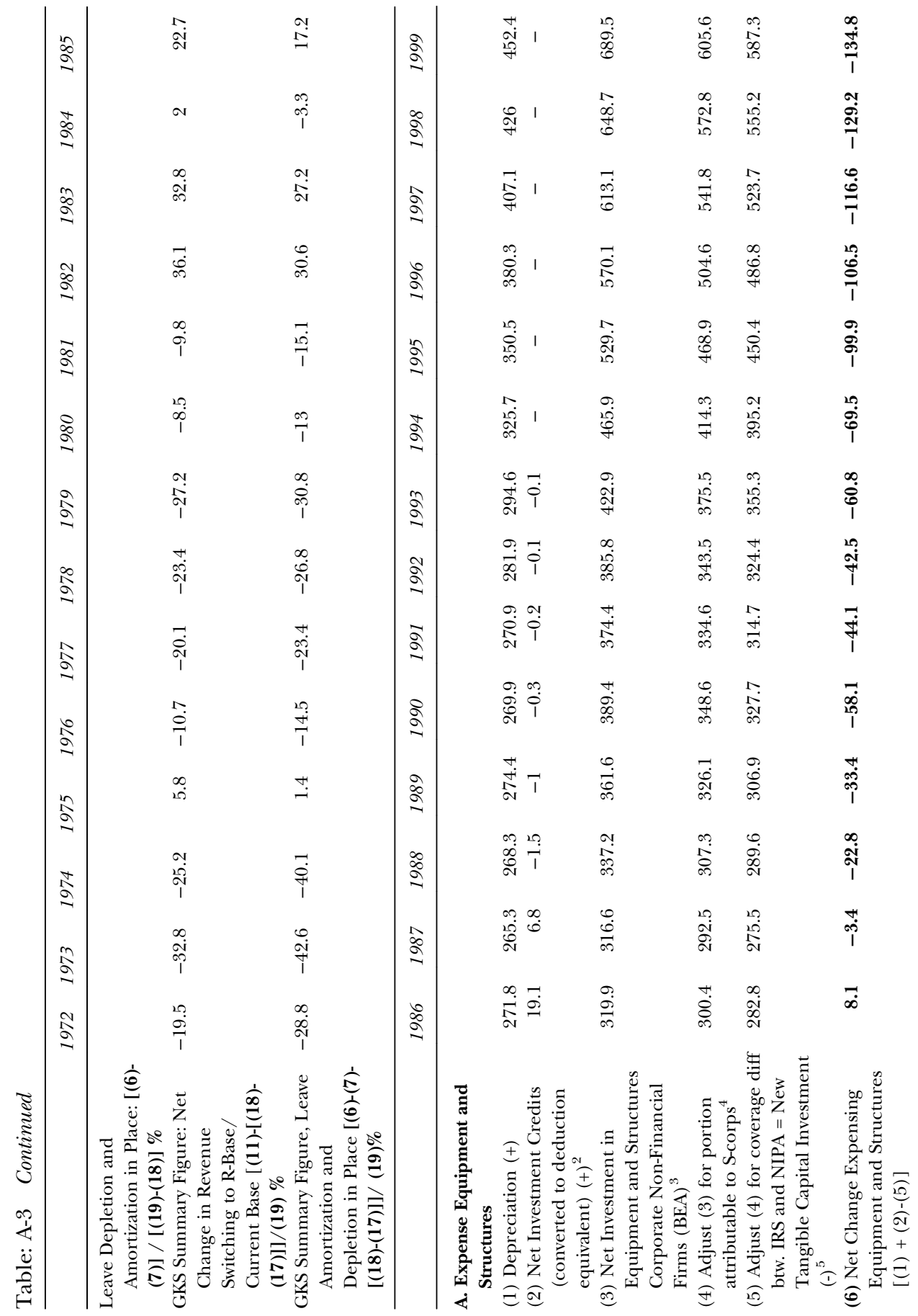




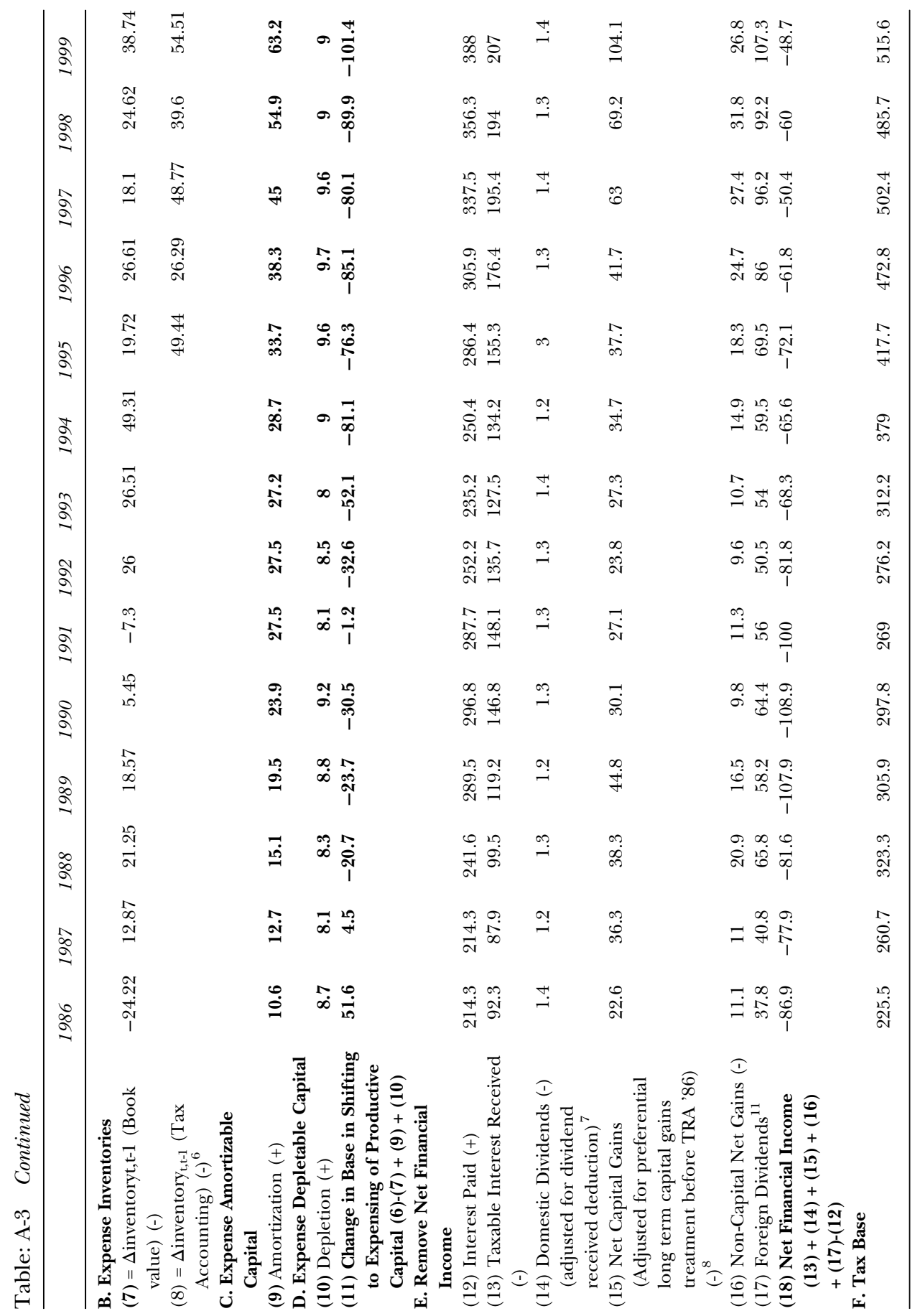




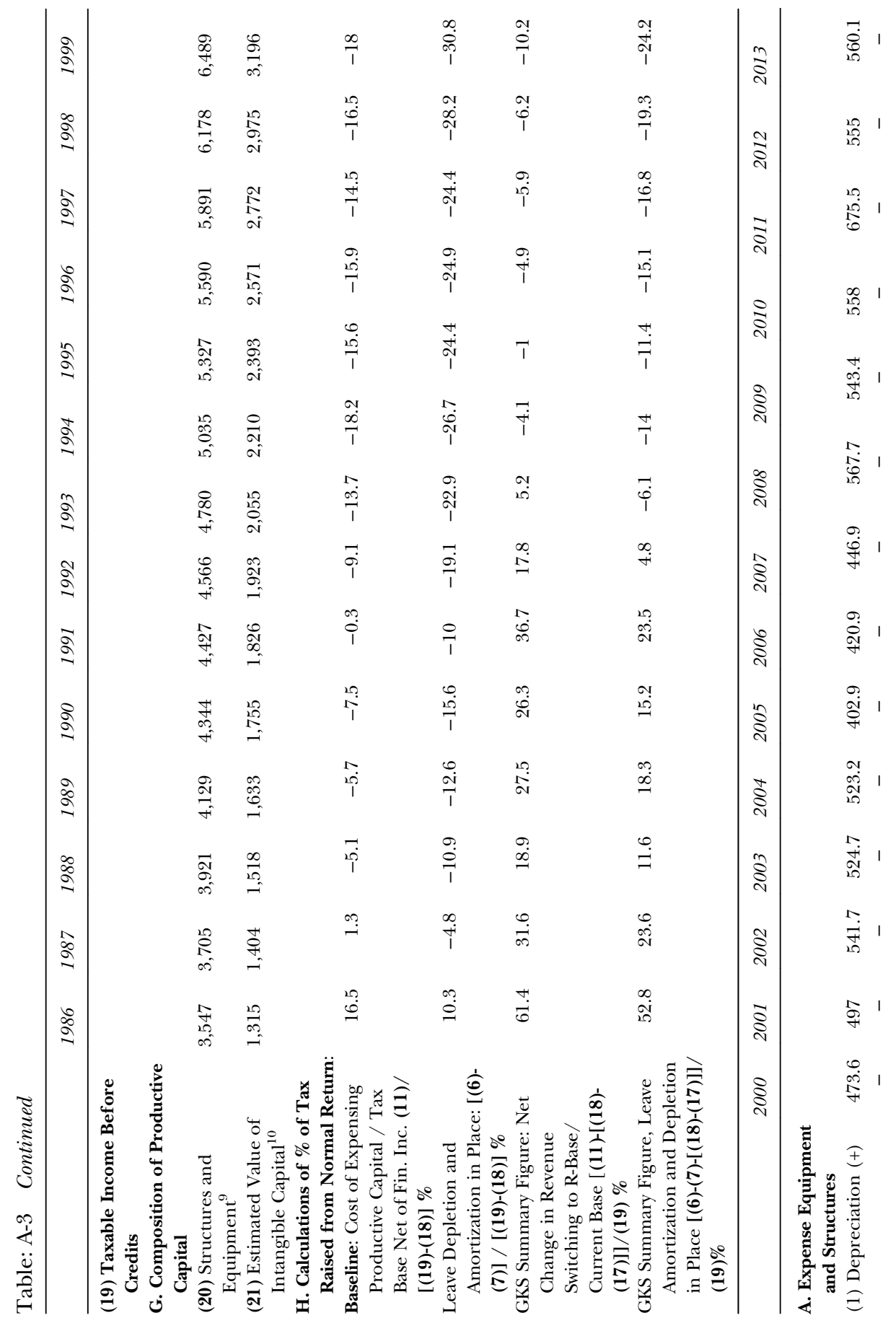




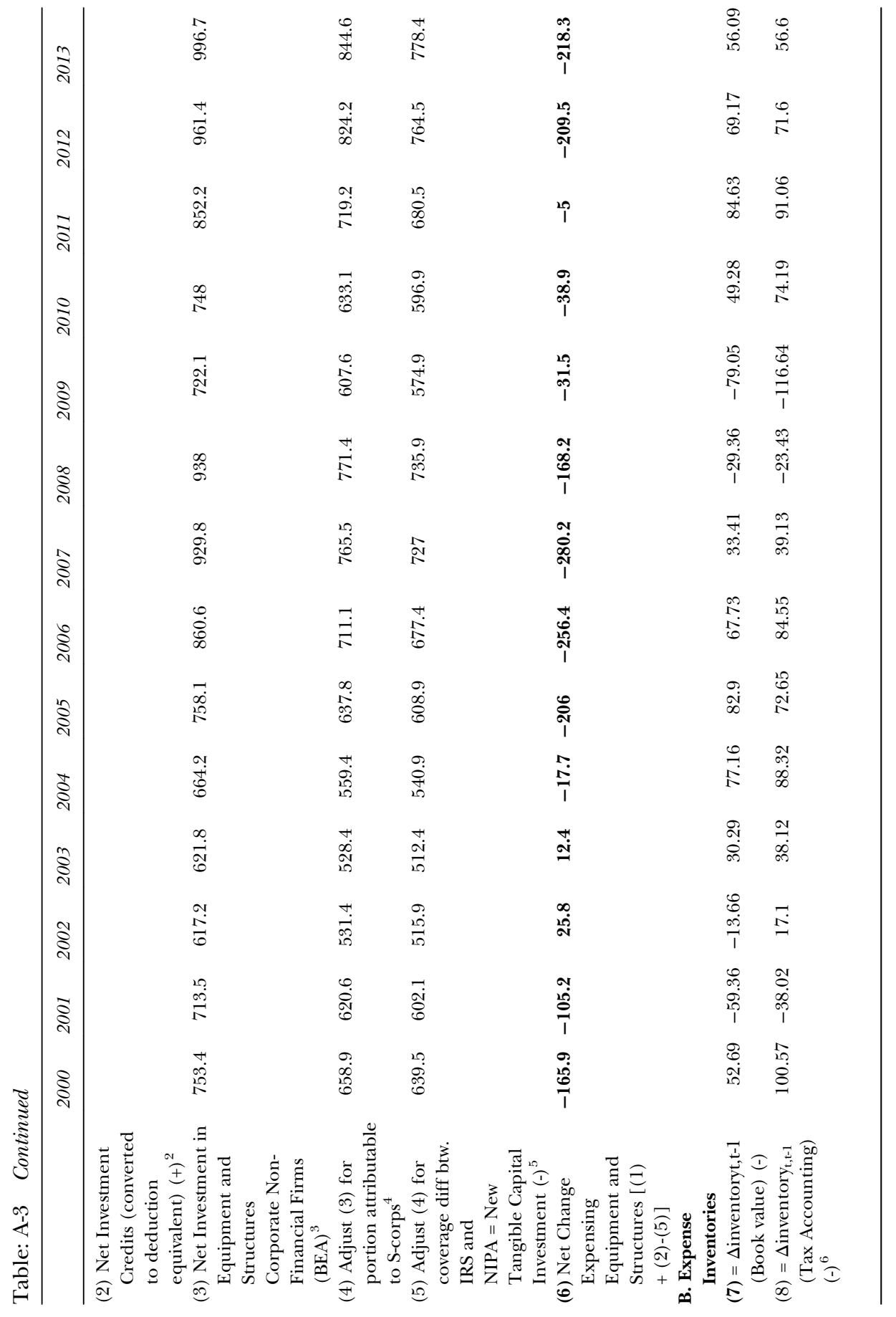




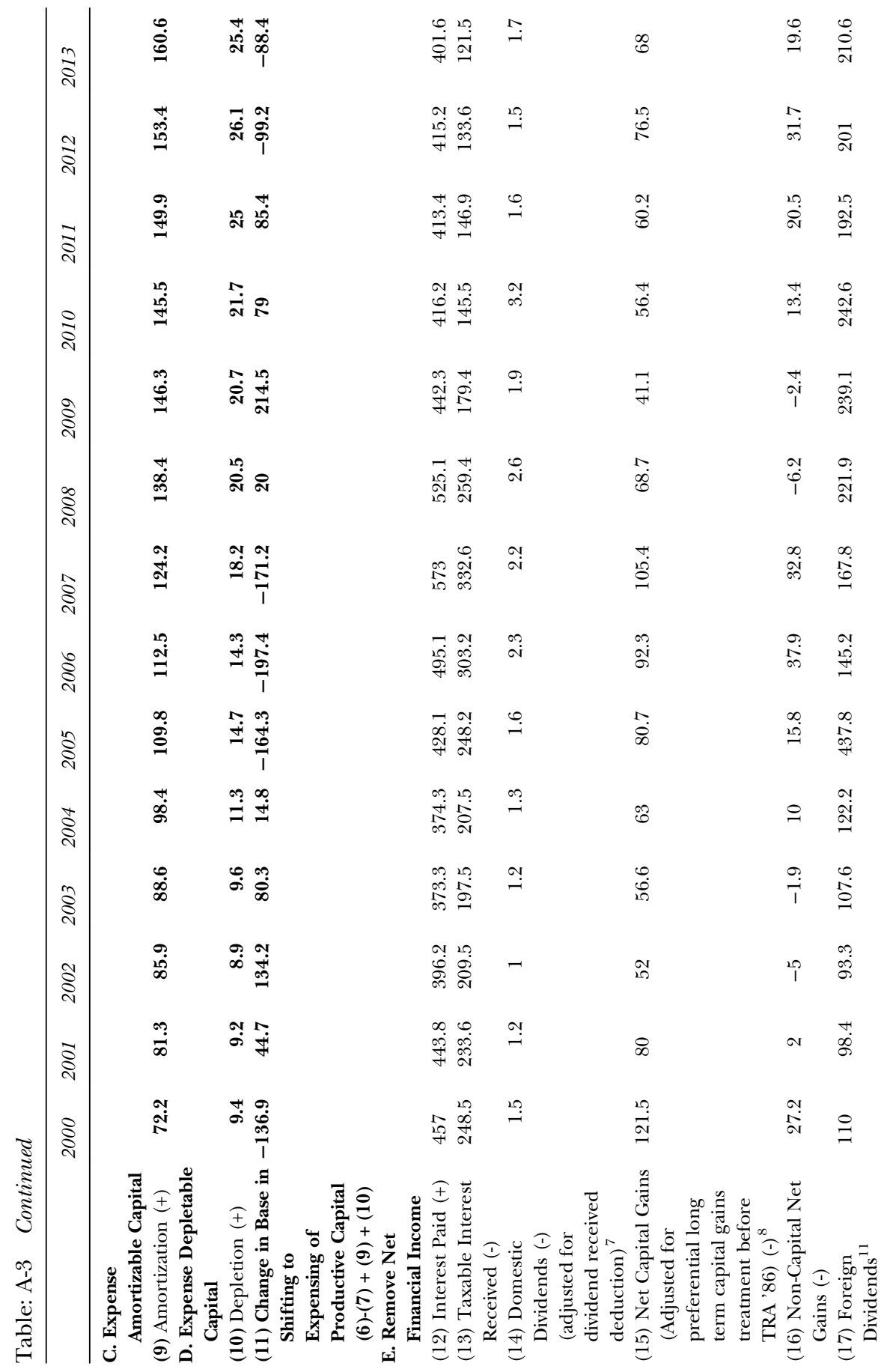




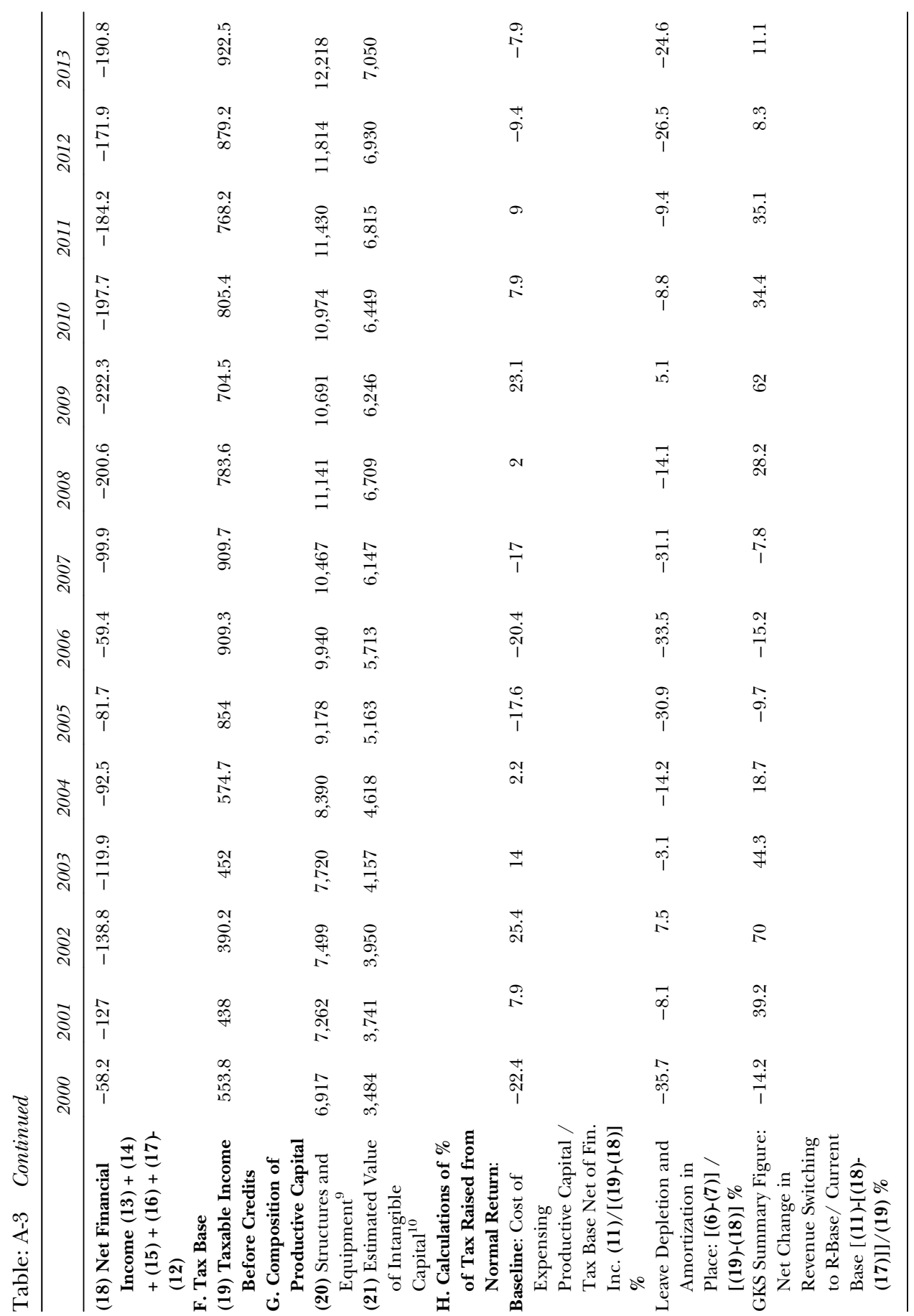




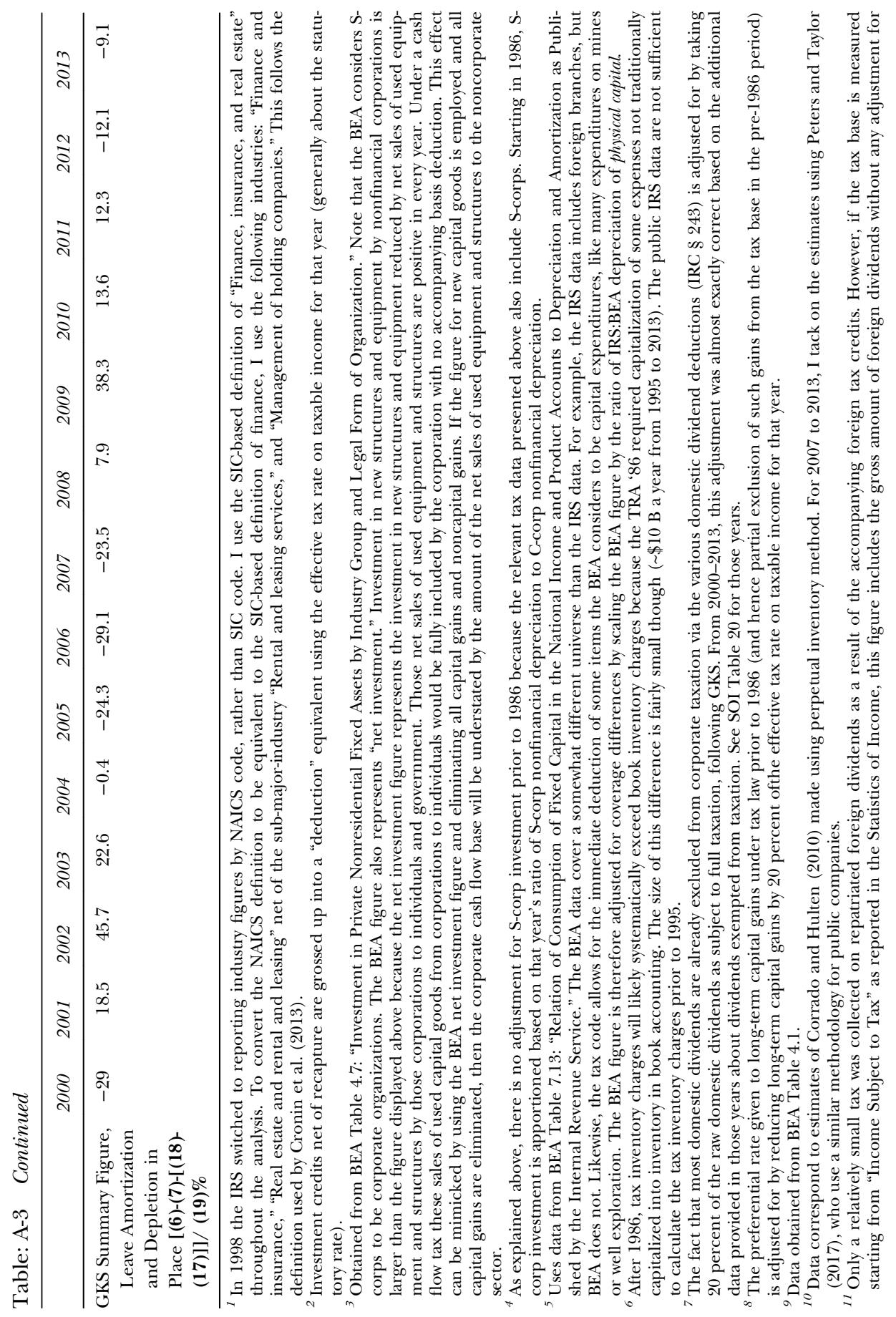




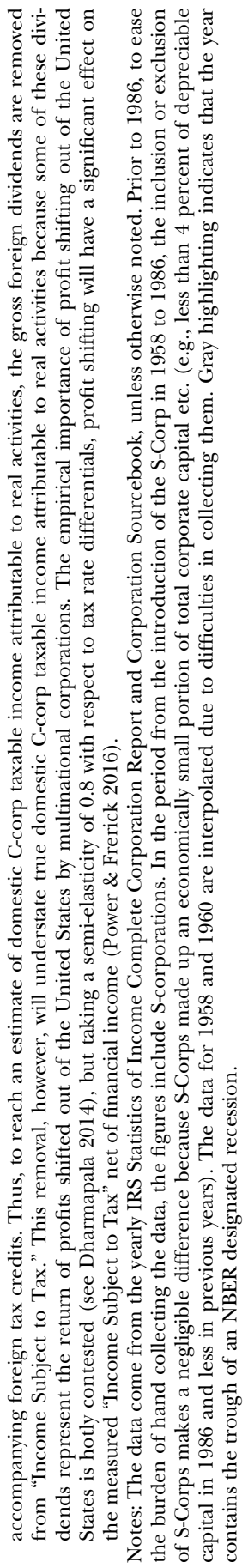

